\title{
BUFFER CAPACITY IN HETEROGENEOUS MULTICOMPONENT SYSTEMS. REVIEW
}

\author{
Oxana Spinu*, Igor Povar \\ Institute of Chemistry of Academy of Sciences of Moldova, 3, Academiei str., Chisinau MD-2028, Republic of Moldova \\ *e-mail: oxana_spinu@yahoo.com; phone (+373 22) 739736
}

\begin{abstract}
The quantitative basis of the theory of buffer properties for two-phase acid-base buffer systems and for multicomponent heterogeneous systems has been derived. The analytical equations for buffer action with respect to all components for diverse multicomponent systems were deduced. It was found a remarkable relation of proportionality between $\beta_{i}$ quantities. It is shown, that the buffer properties in relation to the solid phase components are amplified with an increase of solubility due to protolytic or complex formation equilibria in saturated solutions. It has been established, that the buffer capacities of components are mutually proportional, whereas for heterogeneous systems these relationships depend on the stoichiometric composition of solid phases. The deduced equations can be applied to the assessment of buffer action of the systems "Natural mineral - soil solution", containing soluble and insoluble chemical species. A number of the important conclusions concerning the investigated buffer systems has been made. The obtained results can be used in various areas of chemical and biochemical researches, especially in soil science, ecological sciences, analytical chemistry, pharmacology, pharmaceutics, medical industry and synthetic organic chemistry
\end{abstract}

Keywords: buffer action, complex formation, thermodynamic stability, extraction multicomponent system, heterogeneous equilibria.

Received: April 2015/Revised final: September 2015/Accepted: September 2015

\section{Introduction}

Buffer capacity is an important concept in many areas of science: analytical and electroanalytical chemistry [1], geochemistry [2], biochemistry [3], medicine and pharmaceutical industry [4], water treatment [5], agriculture [6], environment [7], etc. The capacity of buffer systems to oppose (resist) to the variation of their composition (usually to $\mathrm{pH}$ changes) by influence of external fluxes of chemical compounds of natural or anthropogenic character, that shift chemical equilibria, is called buffer property, and its efficiency - buffer action. Despite of an abundance of the information on buffer systems, the quantitative theory of buffer action has been developed only for mono-phase systems $[8,9]$. The buffer action of mono-phase buffers is usually based on protolytic equilibria between water, a weak acid or base or ampholytic compound and their conjugate pairs $[10,11]$. The widespread use of buffers as well as the variety of chemical processes and phenomena associated with a certain acidity of solutions explains the constant interest in designing and studying new buffer systems.

Unlike the classical mono-phase buffer systems in which the buffer components are dissolved in a unique phase, in two-phase (heterogeneous) buffers they are distributed between two phases: in aqueous phase and solid (gaseous or liquid) phase. The aqueous (buffer) phase contains all the charged particles and a restricted quantity of electro-neutral species. The solid phase contains in significant quantities only electro-neutral particles and serves as their reservoir by means of which the equilibrium is adjusted and one of parameters of buffer system is maintained constantly [9-18]. The buffer action of two-phase systems is based on the shift of complex equilibria, both homogeneous and heterogeneous in the aqueous phase and between phases, respectively [19-21]. By increasing the acidity of solution the role of simultaneous proceeding protolytic reactions with participation of salt anions increases; with an increase of alkalinity the contribution of complex formation reactions occurring with participation of salt cations amplifies. Authors [15] have proved that the buffer capacity is a special case of the sensitivity analysis, as a more general theoretical approach, which studies the answer of system to various external perturbations (as for example, the variation of the certain component concentration). We believe that it is more correct to consider, as a potential reservoir of buffer heterogeneous systems, the complex chemical heterogeneous equilibria with participation of solid phases [16]. Unfortunately, so far there are a small number of studies dedicated to the systematic investigations and the development of theoretical aspects of the buffer action for two-phase systems [8,9,14-21]. Besides, in the majority of these studies only the $p H$-buffer properties of heterogeneous systems were investigated. The concept of "buffer action" helps to find out which reactions control the composition of natural waters, including soil solutions [22-32]. The parameters of buffer action are integrated functions of all the soil chemical components by virtue of their capacity, by means of chemical reactions and sorption-desorption processes, to extinguish or strengthen the effect of entered pollutants [33].

The aim of the present paper has been to develop the quantitative aspects of the buffer action of various components of heterogeneous systems and to establish their interrelation. In this paper, the quantitative aspects of the theory for two-phase buffers with partition equilibria of acid-base pairs between two liquids (aqueous and organic) are 
considered in detail. It is proved that the heterogeneous multicomponent systems possess buffer action with respect to all components " $i$ " of acid-base mixtures. Analytical equations for the buffer capacities of two-phase systems with respect to all the components of heterogeneous systems have been deduced. Moreover, it has been shown that the quantities in these systems are reciprocally proportional. In contrast to classical mono-phase buffers, in two-phase buffer systems the maximum buffer capacity $\beta_{H}$ occurs when $p H_{\max }$ is equal to $p K_{d}+\log (1+P(H A))$, where $K_{d}$ and $P(H A)$ are respectively the dissociation constant and the repartition constant of the acid between two phases.

\section{Theoretical part}

\section{Buffer action of the systems "Mineral - saturated solution"}

The buffer action of soil is one of its fundamental physicochemical characteristics. The soil buffer action composes of the buffer action of a set of mineral and organic components and presented by solid, liquid and gaseous compounds. The buffer capacity of soils in relation to chemical compounds is defined by the content of chemical elements in the soil solution (the parameter of intensity) and on the content of mobile compounds of these elements in solid phases (the parameter of capacity). The buffer capacity of soils can be discovered by the fact that the increase of amounts of toxic metals (TM) is not accompanied by an increase of their content in plants; the different buffer action of the soils in relation to one element is manifested in unequal toxic concentrations for plants [33]. The same soil can possess different buffer action in relation to different metals.

The complexity of the soil solution composition containing mineral phases and a large set of involved chemical compounds determine the possibility of simultaneous chemical reactions along with the capacity of solid phases of minerals to maintain relatively constant the aqueous solution composition [19-21,29-32,34-40]. Under real conditions the buffer action of natural heterogeneous aqueous systems is expressed so as the consumption of any element from solution causes the partial dissolution of solid phases and as a result the composition of the solution is restored.

Currently, extensive information on negative (harmful) transformations of soils, as a result of progressing acid and alkaline loads (in the form of mineral fertilizers, chemicals for protection of plants and industrial emissions dropping out with atmospheric precipitation) has been gathered. Thus, the quantitative assessment of the acid - base buffer action, revealing the degree of influence of the systematic use of fertilizers and technogenic pollution by substances of the acid and alkaline nature is an actual problem of the agrology. Besides, the buffer action of soils contains important information on the processes of soil formation (their orientation and intensity) which is used for the soil diagnostics and classification [33].

As a criterion for quantitative assessment of the intensity of buffer action of the studied multicomponent heterogeneous systems, one can use the value of the buffer capacity $\beta_{i}^{S}$ (the superscript index " $S$ " specifies the presence of solid phases), which can be defined as a partial derivative:

$$
\beta_{i}^{S}=\left(\frac{\partial C_{i}^{0}}{\partial \ln [i]}\right)_{C_{j}^{0}(j \neq i)}
$$

where $C_{i}^{0}$ and $[i]$ denote the initial (analytical) concentration in mixture and equilibrium concentration of the component " $i$ " of solid phase, correspondingly, the subscript index shows that the initial concentrations of other components of the mixture are maintained constant.

We will examine the process of formation of the sparingly soluble salt of arbitrary stoichiometric composition $M_{m} A_{n(S)}(M-$ metal ion, $A$ - anion of salt):

$$
M_{m} A_{n(S)}=m M+n A, \quad K_{S}=[M]^{m}[A]^{n} .
$$

The following set of possible simultaneous reactions in the saturated solution is taken into account:

$$
\begin{aligned}
& M+i H_{2} O=M(O H)_{i}+i H, \quad K_{i}=\left[M(O H)_{i}\right][H]^{i} /[M] \\
& A+j H=H_{j} A, \quad K_{j}=\left[H_{j} A\right] /\left([A][H]^{j}\right) \\
& M+q A+r H=M H_{r} A_{q}, \quad K_{q}=\left[M H_{r} A_{q}\right] /\left([M][H]^{r}[A]^{q}\right) \\
& H_{2} O=H+O H, \quad K_{w}=[H][O H] .
\end{aligned}
$$

For the sake of simplicity, the charges of species are omitted. Near to the reaction equations, the corresponding equilibrium constants are specified. The mass balance $(M B)$ conditions in this system can be formulated by the following equations: 


$$
\begin{aligned}
& C_{M}^{0}=\Delta C_{M}+C_{M}^{r}=\Delta C_{M}+\sum_{i=1} \sum_{j=0} i\left[M_{i}(O H)_{j}\right]+\sum_{q=1} \sum_{r=0}\left[M H_{r} A_{q}\right] \\
& C_{A}^{0}=\Delta C_{A}+C_{A}^{r}=\Delta C_{A}+\sum_{l=0}\left[H_{l} A\right]+\sum_{q=1} \sum_{r=0} q\left[M H_{r} A_{q}\right] \\
& C_{H}^{0}=[H]-[O H]+\sum_{l=1} l\left[H_{l} A\right]-\sum_{i=1} \sum_{j=1} j\left[M_{i}(O H)_{j}\right]+\sum_{q=1} \sum_{r=1} r\left[M H_{r} A_{q}\right]
\end{aligned}
$$

The quantity $C_{i}^{r}$ represents the residual concentration in solution of the ion " $i$ ", e.g. the total concentration of all the species, containing a given ion, while $\Delta C_{i}$ is its molar quantity in the solid phase in 1 L of solution [14-17,41-42]. In the Eq.(8) $C_{H}^{0}$ denotes the excess of $H^{+}$ions in relation to hydroxyl ions in two-phase mixtures $\left(C_{H}^{0}=-C_{O H}^{0}\right)$. The square brackets designate the equilibrium concentrations of species in solution.

From the stoichiometric composition of the solid phase, the following ratio is obtained:

$\frac{\Delta C_{M}}{m}=\frac{\Delta C_{A}}{n}$ or $\Delta C_{A}=\frac{n}{m} \Delta C_{M}$

On the basis of the written equations it is possible to deduce the formulas for calculating the buffer capacity in relation to any component of the mixture. After a series of transformation, one can finally get:

$$
\begin{aligned}
& \beta_{M}^{S}=-\frac{\left(\sum_{i=1} \sum_{j=0} i j\left[M_{i}(\mathrm{OH})_{j}\right]+\frac{m}{n} \sum_{l=1} l\left[H_{l} A\right]-\sum_{q=1} \sum_{r=1} r\left[M H_{r} A_{q}\right]+\frac{m}{n} \sum_{q=1} \sum_{r=1} r q\left[M H_{r} A_{q}\right]\right)^{2}}{[H]+[O H]+\sum_{l=1} l^{2}\left[H_{l} A\right]+\sum_{i=1} \sum_{j=0} j^{2}\left[M_{i}(O H)_{j}\right]+\sum_{q=1} \sum_{r=1} r^{2}\left[M H_{r} A_{q}\right]}+ \\
& +\frac{m^{2}}{n^{2}} \sum_{l=0}\left[H_{l} A\right]+\sum_{q=1}\left(\frac{m^{2} q^{2}}{n^{2}}-2 \frac{m q}{n}+1\right) \sum_{q=1} \sum_{r=0}\left[M H_{r} A_{q}\right]+\sum_{i=1} \sum_{j=0} i^{2}\left[M_{i}(O H)_{j}\right]
\end{aligned}
$$

or

$$
\beta_{M}^{S}=\varphi_{3}-\frac{\varphi_{1}^{2}}{\varphi_{2}}
$$

where $\varphi_{1,} \varphi_{2}$ and $\varphi_{3}$ denote the following concentration functions:

$$
\begin{aligned}
& \varphi_{1}=\sum_{i=1} \sum_{j=0} i j\left[M_{i}(O H)_{j}\right]+\frac{m}{n} \sum_{l=1} l\left[H_{l} A\right]-\sum_{q=1} \sum_{r=1} r\left[M H_{r} A_{q}\right]+\frac{m}{n} \sum_{q=1} \sum_{r=1} r q\left[M H_{r} A_{q}\right] \\
& \varphi_{2}=[H]+[O H]+\sum_{l=1} l^{2}\left[H_{l} A\right]+\sum_{i=1} \sum_{j=0} j^{2}\left[M_{i}(O H)_{j}\right]+\sum_{q=1} \sum_{r=1} r^{2}\left[M H_{r} A_{q}\right] \\
& \varphi_{3}=\frac{m^{2}}{n^{2}} \sum_{l=0}\left[H_{l} A\right]+\sum_{q=1}\left(\frac{m^{2} q^{2}}{n^{2}}-2 \frac{m q}{n}+1\right) \sum_{q=1} \sum_{r=0}\left[M H_{r} A_{q}\right]+\sum_{i=1} \sum_{j=0} i^{2}\left[M_{i}(O H)_{j}\right]
\end{aligned}
$$
valid:

Similarly, it is possible to prove that, for the buffer capacity towards proton, the following expression is

$$
\left(\frac{\partial C_{H}^{0}}{\partial \ln [H]}\right)_{C_{M}^{0}, C_{A}^{0}} \equiv \beta_{H}^{S}=\varphi_{2}-\frac{\varphi_{1}^{2}}{\varphi_{3}}
$$

For the buffer capacity towards the anion of the solid phase one can deduce:

$$
\beta_{A}^{S}=\frac{n^{2}}{m^{2}} \varphi_{3}-\frac{n^{2}}{m^{2}} \frac{\varphi_{1}^{2}}{\varphi_{2}}=\frac{n^{2}}{m^{2}}\left(\varphi_{3}-\frac{\varphi_{1}^{2}}{\varphi_{2}}\right)=\frac{n^{2}}{m^{2}} \beta_{M}^{S}
$$


On the basis of obtained Eq.(11), Eq.(13) and Eq.(14) the following remarkable conclusion follows: the buffer capacities towards different components are reciprocally proportional, while the buffer capacities in relation to the ions of the solid phase are interconnected through its stoichiometric coefficients:

$$
\frac{\beta_{A}^{S}}{n^{2}}=\frac{\beta_{M}^{S}}{m^{2}}
$$

It is worthy to mention that the obtained relations are only valid in the presence of the mineral (solid phase) $M_{m} A_{n(S)}$. The thermodynamic stability area of the latter is determined by the value of the Gibbs energy of the overall process (1)-(5) $[14,43,44]$ :

$$
\Delta G_{S, t o t}=-m R T \ln \frac{C_{M}^{r}}{C_{M}^{0}}-n R T \ln \frac{C_{A}^{r}}{C_{A}^{0}}
$$

The solid-phase is stable if $\Delta G_{S, t o t}>0$. The condition $\Delta G_{S, t o t}=0$ corresponds to the beginning of its dissolution and (or) sedimentation.

The analysis of the derived equations shows that the buffer capacities grow with the increase of the precipitate solubility, e.g. by rising the residual concentration of the component of minerals.

\section{Buffer properties for liquid two-phase acid-base buffer systems}

The concept of buffering is closely related to the problem of controlling the chemical composition of multicomponent systems. For analytical chemists it is essential to preserve as a constant not only the $\mathrm{pH}$ value (e.g., the proton concentration), but the concentrations of other components in the system. In the examined extraction systems, the organic phase serves as the buffer reservoir [31,45-47]. At present, for these systems there is no rigorous theoretical base allowing a priori estimation of their buffer effectiveness as well as a systematic search for new heterogeneous mixtures with high buffer action. Janjić et al. [45] have investigated the buffer action with respect to the hydrogen ion (proton) for the multicomponent two-phase systems containing both separate organic acids and bases, and their mixtures. These authors made an attempt to deduce an equation for an assessment of buffer capacity of such systems. However, the obtained expressions are bulky and in some cases neglect a number of side equilibria, occurring in the organic phase.

For two-phase buffers with polyprotic acids, the following process of formation in aqueous solution of the polyprotic acid of stoichiometric composition $H_{n} A$ takes place:

$n H+A \leftrightarrow H_{n} A, \quad K_{n}=\left[H_{n} A\right] /\left([H]^{n}[A]\right)$

The following set of concomitantly reactions proceeding in two-phase systems "Aqueous solution $(a q)$ - organic solvent (o)" proceeds:

$H_{k} A_{(a q)} \leftrightarrow H_{k} A_{(o)}, \quad P\left(H_{k} A\right)=\left[H_{k} A\right]_{o} /\left[H_{k} A\right]_{a q}$

$\mathrm{H}_{2} \mathrm{O} \leftrightarrow \mathrm{H}+\mathrm{OH}, \quad \mathrm{K}_{w}=[\mathrm{H}][\mathrm{OH}]$

Here and below, for sake of convenience, the charges of species are omitted, the subscript $(a q)$ is also neglected in the case of equilibria taking place only in aqueous solution. Near to equations the associated equilibrium constants are specified: $K_{n}$ is the protonation constant of polyprotic acid $H_{n} A$ and $P\left(H_{k} A\right)$ is the constant of distribution of the molecular acid $H_{k} A$ between two non-mixing liquids. For simplicity, it has been assumed that the system obeys ideal behavior of the studied systems where the ionic strength is zero. Consequently, the ion activities are equal to their concentrations, while the activity of pure species is equal to unity (or included in the equilibrium constants) $[24,25,48,49]$. The conditions of mass balance in the given heterogeneous system can be formulated as follows:

$$
\begin{aligned}
& C_{A}^{0} \equiv \widetilde{a}=\sum_{n=0}\left[H_{n} A\right]_{a q}+\left[H_{k} A\right]_{O}=[A]\left(1+\sum_{n=1} K_{n}[H]^{n}\right)+P\left(H_{k} A\right) K_{k}[H]^{k}[A] \\
& C_{H}^{0}=[H]-[O H]+\sum_{n=1} n\left[H_{n} A\right]+k\left[H_{k} A\right]_{o}=[H]-K_{W}[H]^{-1}+[A] \sum_{n=1} n K_{n}[H]^{n}+k P\left(H_{k} A\right) K_{k}[H]^{k}[A]
\end{aligned}
$$


The $C_{A}^{0}$ value in the Eq.(20) represents the analytical concentration of the anion $A^{n-1}$ of acid in considered heterogeneous system. In the Eq.(21) $C_{H}^{0}$ denotes the excess of $H^{+}$ions towards to hydroxyl - ions in the two-phase mixture $\left(C_{H}^{0}=-C_{O H}^{0}\right)[12]$. When deducing Eq.(20) and Eq.(21) it was assumed that the volume of water phase $V_{a q}$ is equal to the volume of organic phase $V_{o}$ :

$V_{a q}=V_{o}$

We present here only final results, omitting the intermediate deduction of the equations through the equilibrium constants Eqs.(17) - (19) as it has been done in the Eqs.(20) and (21):

$\beta_{A}=\left(\frac{\partial C_{A}^{0}}{\partial \ln [A]}\right)_{C_{H}^{0}}=\sum_{n=0}\left[H_{n} A\right]_{a q}+\left[H_{k} A\right]_{O}+\left(\frac{\partial \ln [H]}{\partial \ln [A]}\right)_{C_{H}^{0}}\left(\sum_{n=1} n\left[H_{n} A\right]+k\left[H_{k} A\right]_{O}\right) \equiv \tilde{a}+\widetilde{n}\left(\frac{\partial \ln [H]}{\partial \ln [A]}\right)_{C_{H}^{0}}$

where through $\tilde{n}$ is designated the sum that the third member of the Eq.(23) contains. Considering that $C_{H}^{0}=$ const :

$\left(\frac{\partial C_{H}^{0}}{\partial \ln [A]}\right)_{C_{H}^{0}}=0=\tilde{n}+\left([H]+[O H]+\sum_{n=1} n^{2}\left[H_{n} A\right]+k^{2}\left[H_{k} A\right]_{o}\right)\left(\frac{\partial \ln [H]}{\partial \ln [A]}\right)_{C_{H}^{0}} \equiv \widetilde{n}+\widetilde{h}\left(\frac{\partial \ln [H]}{\partial \ln [A]}\right)_{C_{H}^{0}}$

Whence

$\left(\frac{\partial \ln [H]}{\partial \ln [A]}\right)_{C_{H}^{0}}=-\frac{\tilde{n}}{\widetilde{h}}$

Substituting the obtained expression for the partial derivative Eq.(24) in the Eq.(23), it is finally received:

$\beta_{A}=\widetilde{a}-\frac{\widetilde{n}^{2}}{h}=C_{A}^{0}-\frac{\left(\sum_{n=1} n\left[H_{n} A\right]+k\left[H_{k} A\right]_{o}\right)^{2}}{[H]+[O H]+\sum_{n=1} n^{2}\left[H_{n} A\right]+k^{2}\left[H_{k} A\right]_{o}}$

In the case of monoprotic acid $H A, n=1$, within the range of $p H$ values, where the concentrations of $\left[H^{+}\right]$and $\left[\mathrm{OH}^{-}\right]$can be neglected, the Eq.(26) becomes significantly simpler, $\beta_{A} \cong[A]$, e.g. the buffer capacity is equal to the equilibrium concentration of the anion of acid.

In a similar way, for the buffer capacity in relation to proton, it is possible to obtain the following expression:

$\beta_{H} \equiv\left(\frac{\partial C_{H}^{0}}{\partial \ln [H]}\right)_{C_{A}^{0}}=[H]+[O H]+\sum_{n=1} n^{2}[H]^{n}+k^{2}\left[H_{k} A\right]_{o}^{k}-\frac{\left(\sum_{n=1} n\left[H_{n} A\right]+k\left[H_{k} A\right]\right)^{2}}{C_{A}^{0}} \equiv \widetilde{h}-\widetilde{n}^{2} / \widetilde{a}$

It is important to notice, that for monoprotic acid the Eq.(27) simplifies significantly:

$$
\beta_{H} \equiv\left(\frac{\partial C_{H}^{0}}{\partial \ln [H]}\right)_{C_{A}^{0}}=[H]+[O H]+[H A]+[H A]_{o}-\frac{\left([H A]+[H A]_{o}\right)^{2}}{C_{A}^{0}}
$$

The maximum buffer capacity for a given $C_{A}^{0}$ occurs when $\left(\partial \beta_{H} / \partial \ln [H]\right)_{C_{A}^{0}}=0$, i.e. when:

$p H_{\max }=p K_{d}+\log (1+P(H A)) \quad$,

where $K_{d}=1 / K_{1}$ is the dissociation constant of weak acid $H A$. It is well-known that for the mono-phase buffer system $p H_{\max }=p K_{d}$. Consequently, in comparison with classical aqueous buffers, the $p H_{\max }$ value in the case of two-phase systems is shifted by $\log (1+P(H A))$, which depends mainly on the nature of organic solvent. From the Eqs.(26) and (27) a remarkable identity follows:

$\beta_{A} \tilde{h}=\beta_{H} \tilde{a}$ 
Therefore, the investigated heterogeneous system shows buffer properties with respect to both ions of the polyprotic acid, and the values of buffer capacity $\beta_{A}$ and $\beta_{H}$ are reciprocally proportional. For monoprotic acids, since $h=[H]+[\mathrm{OH}]+[H A]+[H A]_{o}$ and $\tilde{a}=C_{A}^{0}$, the identity Eq.(30) becomes:

$\left.\beta_{A}=(H]+[O H]+[H A]+[H A]_{o}\right)=\beta_{H}\left([A]+[H A]+[H A]_{o}\right)$.

Similarly, it is possible to obtain the expressions for calculating the buffer capacities in the case of the polyprotic base $\mathrm{BH}_{m}$ as well.

\section{Results and discussion}

Buffer action of heterogeneous system "Mineral - saturated solutions"

The buffer action of heterogeneous system "Mineral - saturated solutions" depends on the chemical composition of the water solutions, as well as on the composition and properties of the mineral phases. We will examine a concrete real system "Iron (III) minerals - saturated solution", although the approach developed here can be applied for any other. As iron occurs in many minerals and materials, it is mostly present in all superficial waters. The average concentration of iron in river waters is $0.7 \mathrm{mg} / \mathrm{L}$ [50]. With an increase of the acidity of waters (up to a critical threshold of water biota survival; for example, for mollusks this threshold is $p H 6.0$ and for perches it is $p H 4.5$ ), the content of iron (III) increases rapidly because of the interaction of iron (III) hydroxide of natural materials with acid:

$$
\begin{aligned}
& \frac{1}{2} \mathrm{Fe}_{2} \mathrm{O}_{3(S)}+3 \mathrm{H}^{+} \Leftrightarrow \mathrm{Fe}^{3+}+\frac{3}{2} \mathrm{H}_{2} \mathrm{O}, K_{S 1}=\left[\mathrm{Fe}^{3+}\right]\left[\mathrm{H}^{+}\right]^{-3} \\
& \mathrm{FeOOH}_{3(S)}+3 \mathrm{H}^{+} \Leftrightarrow \mathrm{Fe}^{3+}+2 \mathrm{H}_{2} \mathrm{O}, K_{S 2}=\left[\mathrm{Fe}^{3+}\right]\left[\mathrm{H}^{+}\right]^{-3} \\
& \mathrm{Fe}(\mathrm{OH})_{3(S)}+3 \mathrm{H}^{+} \Leftrightarrow \mathrm{Fe}^{3+}+3 \mathrm{H}_{2} \mathrm{O}, K_{S 3}=\left[\mathrm{Fe}^{3+}\right]\left[\mathrm{H}^{+}\right]^{-3}
\end{aligned}
$$

We find the following important relation of proportionality between the buffer capacities of heterogeneous systems, " $\mathrm{Fe}(\mathrm{OH})_{3(\mathrm{~S})}$ - saturated aqueous solution":

$$
\beta_{H}^{S}=3^{2} \beta_{F e}^{S}
$$

In the case of formation of poorly soluble oxy-hydroxides of the stoichiometric composition $M(\mathrm{OH})_{n(S)}, \mathrm{MOOH}_{(S)}$ or $1 / 2 M_{2} O_{n(S)}$, the relation (31) can be generalized $[14,16,51]$ :

$$
\frac{\beta_{H}^{S}}{n^{2}}=\frac{\beta_{M}^{S}}{1^{2}}
$$

Besides the process of dissolution of the mineral of iron, a set of possible equilibria in the system "Mineral

\begin{tabular}{|c|c|}
\hline The equations of reactions & $\log K$ \\
\hline $\mathrm{Fe}^{3+}+\mathrm{H}_{2} \mathrm{O}=\mathrm{FeOH}{ }^{2+}+\mathrm{H}^{+}$ & -2.187 \\
\hline $\mathrm{Fe}^{3+}+2 \mathrm{H}_{2} \mathrm{O}=\mathrm{Fe}(\mathrm{OH})_{2}^{+}+2 \mathrm{H}^{+}$ & -4.59 \\
\hline $\mathrm{Fe}^{3+}+3 \mathrm{H}_{2} \mathrm{O}=\mathrm{Fe}(\mathrm{OH})_{3}^{0}+2 \mathrm{H}^{+}$ & -12.56 \\
\hline $\mathrm{Fe}^{3+}+4 \mathrm{H}_{2} \mathrm{O}=\mathrm{Fe}(\mathrm{OH})_{4}^{-}+4 \mathrm{H}^{+}$ & -21.59 \\
\hline $1 / 2 \alpha-\mathrm{Fe}_{2} \mathrm{O}_{3(S) \text { hematite }}+3 \mathrm{H}^{+}=\mathrm{Fe}^{3+}+3 / 2 \mathrm{H}_{2} \mathrm{O}$ & -0.85 \\
\hline $1 / 2 \gamma-\mathrm{Fe}_{2} \mathrm{O}_{3(S) \text { maghemite }}+3 \mathrm{H}^{+}=\mathrm{Fe}^{3+}+3 / 2 \mathrm{H}_{2} \mathrm{O}$ & +1.75 \\
\hline $1 / 2 \varepsilon-\mathrm{Fe}_{2} \mathrm{O}_{3(S)}+3 \mathrm{H}^{+}=\mathrm{Fe}^{3+}+3 / 2 \mathrm{H}_{2} \mathrm{O}$ & +2.35 \\
\hline 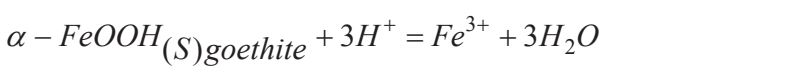 & +0.40 \\
\hline$\gamma-\mathrm{FeOOH}_{(S) \text { lepidocrocite }}+3 \mathrm{H}^{+}=\mathrm{Fe}^{3+}+3 \mathrm{H}_{2} \mathrm{O}$ & +3.70 \\
\hline
\end{tabular}
phase - soil solution" (see Table 1) is considered [52]. For the calculations the following composition heterogeneous mixture was used $\left(\mathrm{mol} \mathrm{L}^{-1}\right): C_{\mathrm{Fe}}^{0}=1 \cdot 10^{-6} \div 1 \cdot 10^{-4}, C_{F}^{0}=5 \cdot 10^{-6}, C_{\mathrm{Org}}^{0}=C_{\mathrm{PO}_{4}}^{0}=C_{\mathrm{SO}_{4}}^{0}=1 \cdot 10^{-4}, C_{\mathrm{CO}_{3}}^{0}=1 \cdot 10^{-3}$.

Table 1

\section{The equilibrium constants of the analyzed reactions.}




\begin{tabular}{lc}
\hline \multicolumn{1}{c}{ Equations of reactions } & $\log \mathrm{K}$ \\
\hline $2-$ line $-\mathrm{Fe}(\mathrm{OH})_{3(\mathrm{~S})}+3 \mathrm{H}^{+}=\mathrm{Fe}^{3+}+3 \mathrm{H}_{2} \mathrm{O}$ & +3.00 \\
$6-$ line $-\mathrm{Fe}(\mathrm{OH})_{3(\mathrm{~S})}+3 \mathrm{H}^{+}=\mathrm{Fe}^{3+}+3 \mathrm{H}_{2} \mathrm{O}$ & +3.40 \\
$\mathrm{Fe}^{3+}+\mathrm{F}^{-}=\mathrm{FeF}^{2+}$ & 6.04 \\
$\mathrm{Fe}^{3+}+2 \mathrm{~F}^{-}=\mathrm{FeF}_{2}^{+}$ & 10.47 \\
$\mathrm{Fe}^{3+}+\mathrm{SO}_{4}^{2-}=\mathrm{Fe}\left(\mathrm{SO}_{4}\right)^{+}$ & 4.05 \\
$\left.\mathrm{Fe}^{3+}+2 \mathrm{SO}_{4}^{2-}=\mathrm{Fe}^{2-} \mathrm{SO}_{4}\right)_{2}^{-}$ & 5.38 \\
$\mathrm{Fe}^{3+}+\mathrm{H}^{+}+2 \mathrm{SO}_{4}^{2-}=\mathrm{FeH}_{\left(\mathrm{SO}_{4}\right)_{2}}$ & 8.10 \\
$\mathrm{Fe}^{3+}+\mathrm{Org}^{3-}=\mathrm{FeOrg}^{3-}$ & 8.00 \\
$\mathrm{Org}^{3-}+\mathrm{H}^{+}=\mathrm{HOrg}^{2-}$ & 4.30 \\
$2 \mathrm{Fe}^{3+}+2 \mathrm{H}_{2} \mathrm{O}=\mathrm{Fe}_{2}\left(\mathrm{OH}_{2}^{4+}+2 \mathrm{H}^{+}\right.$ & -2.85 \\
$3 \mathrm{Fe}^{3+}+4 \mathrm{H}_{2} \mathrm{O}=\mathrm{Fe}_{3}\left(\mathrm{OH}_{4}^{5+}+4 \mathrm{H}^{+}\right.$ & -6.29 \\
$\mathrm{Fe}^{3+}+\mathrm{H}^{+}+\mathrm{PO}_{4}^{3-}=\mathrm{FeHPO}_{4}^{+}$ & 19.87 \\
$\mathrm{Fe}^{3+}+2 \mathrm{H}^{+}+\mathrm{PO}_{4}^{3-}=\mathrm{FeH}_{2} \mathrm{PO}_{4}^{2+}$ & 21.70 \\
$\mathrm{Fe}^{3+}+3 \mathrm{H}^{+}+\mathrm{PO}_{4}^{3-}=\mathrm{FeH}_{3} \mathrm{PO}_{4}^{3+}$ & 26.61 \\
$\mathrm{CO}_{3}^{2-}+\mathrm{H}^{+}=\mathrm{HCO}_{3}^{-}$ & 10.329 \\
$\mathrm{CO}_{3}^{2-}+2 \mathrm{H}^{+}=\mathrm{H}_{2} \mathrm{CO}_{3}$ & 16.681 \\
$\mathrm{H}^{+}+\mathrm{PO}_{4}^{3-}=\mathrm{HPO}_{4}^{2+}$ & 12.38 \\
$2 \mathrm{H}^{+}+\mathrm{PO}_{4}^{3-}=\mathrm{H}_{2} \mathrm{PO}_{4}^{+}$ & 19.57 \\
$3 \mathrm{H}^{+}+\mathrm{PO}_{4}^{3-}=\mathrm{H}_{3} \mathrm{PO}_{4}$ & 21.72 \\
$\mathrm{H}^{+}+\mathrm{F}^{-}=\mathrm{HF}^{+}$ & 3.17 \\
\hline
\end{tabular}

Figure 1 shows the calculation results of the buffer capacity $\beta_{F e}^{S}$ as a function of $p H$ for the various iron (III) minerals. The analysis of the derived equations for the heterogeneous system showed that the increase in the total concentration $C_{F e}^{0}$ for the $p H$ values above 4.5, as well as the nature of the mineral have an insignificant effect on the area of the buffer action of studied system due to the very low solubility of iron oxy - hydroxides minerals. The appearance of maxima on the curves $\beta_{H}^{S}(p H)$ and $\beta_{F e}^{S}(p H)$ (Figures 1-3) is due to the dissociation process of carbonic acid with formation of $\mathrm{HCO}_{3}^{-}$ions $(\mathrm{pH}=6.36)$ and $\mathrm{CO}_{3}{ }^{2-}(\mathrm{pH}=10.34)$.

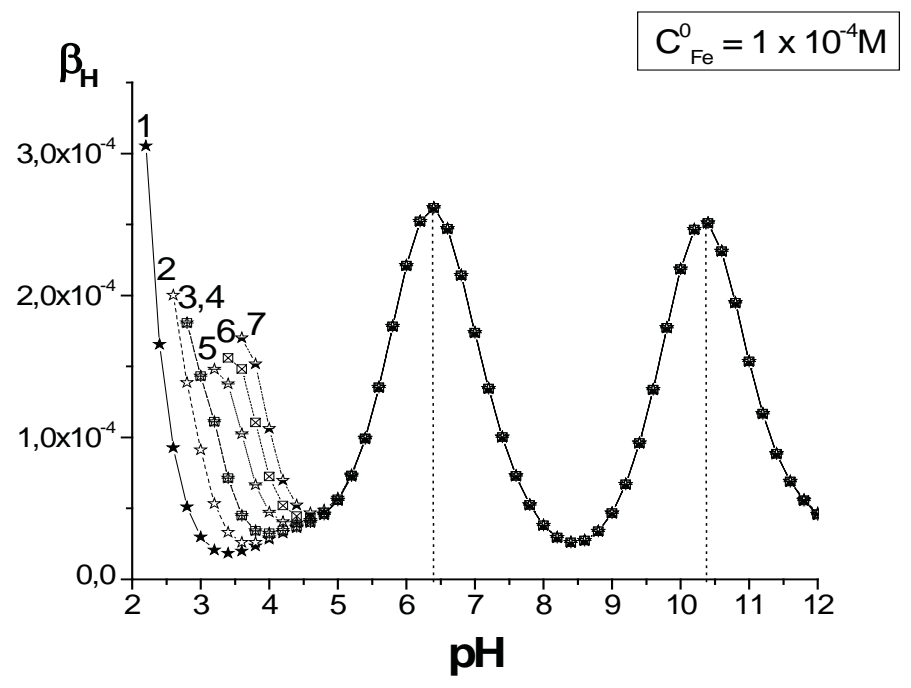

Figure 1. The curves of dependence of the buffer capacity $\boldsymbol{\beta}_{H}$ on $\mathrm{pH}$ for the system "Iron (III) mineral - saturated aqueous solution". The used concentrations $\left(\mathrm{mol} \mathrm{L}^{-1}\right)$ :

$\mathrm{C}_{\mathrm{Fe}}^{0}=1 \cdot 10^{-4}, \mathrm{C}_{\mathrm{F}}^{0}=5 \cdot 10^{-6}$,

$\mathrm{C}_{\mathrm{Org}}^{0}=\mathrm{C}_{\mathrm{PO}_{4}}^{0}=\mathrm{C}_{\mathrm{SO}_{4}}^{0}=1 \cdot 10^{-4}$, $\mathrm{C}_{\mathrm{CO}_{3}}^{0}=1 \cdot 10^{-3}$

$1-\alpha-\mathrm{Fe}_{2} \mathrm{O}_{3}$ (hematite),

$2-\gamma-\mathrm{Fe}_{2} \mathrm{O}_{3}$ (maghemite),

$3-\varepsilon_{-}-\mathrm{Fe}_{2} \mathrm{O}_{3}$,

4 - $\alpha-\mathrm{FeOOH}$ (goethite),

5 - $\gamma$-FeOOH (lepidocrocite),

6 - $\mathrm{Fe}(\mathrm{OH})_{3}$ (2-line ferrihydrite),

$7-\mathrm{Fe}(\mathrm{OH})_{3}$ (6-line ferrihydrite). 


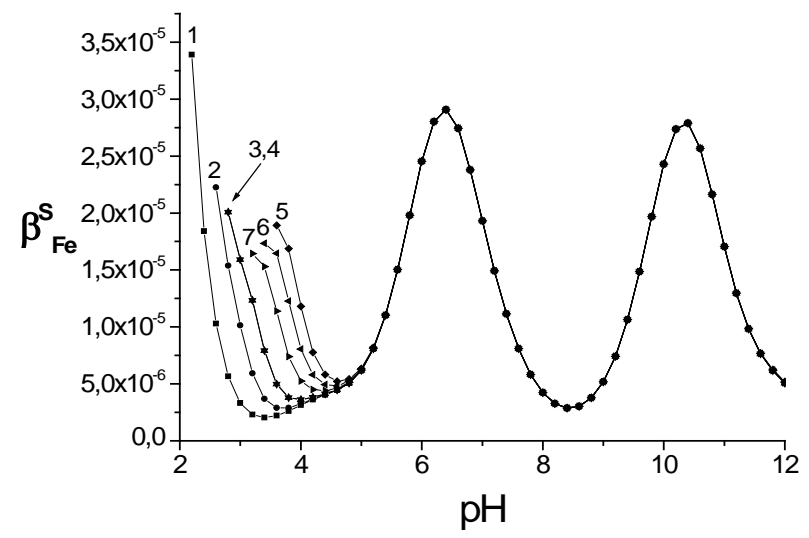

Figure 2. The curves of dependence of the buffer capacity $\beta_{F e}^{S}$ on $\mathbf{p H}$ for the system

"Iron (III) mineral - saturated aqueous solution". The used concentrations $\left(\mathrm{mol} \mathrm{L}^{-1}\right)$ :

$$
\mathrm{C}_{\mathrm{Fe}}^{0}=1 \cdot 10^{-4}, \mathrm{C}_{\mathrm{F}}^{0}=\mathbf{5} \cdot 10^{-6}, \mathrm{C}_{\mathrm{Org}}^{0}=\mathrm{C}_{\mathrm{PO}_{4}}^{0}=\mathrm{C}_{\mathrm{SO}_{4}}^{0}=1 \cdot 10^{-4}, \mathrm{C}_{\mathrm{CO}_{3}}^{0}=1 \cdot 10^{-3} \text {. }
$$

$1-\alpha-\mathrm{Fe}_{2} \mathrm{O}_{3}$ (hematite), 2 - $\gamma$ - $\mathrm{Fe}_{2} \mathrm{O}_{3}$ (maghemite), 3 - $-\mathrm{Fe}_{2} \mathrm{O}_{3}, 4-\alpha$-FeOOH (goethite), 5 - $\gamma$-FeOOH (lepidocrocite), 6 - $\mathrm{Fe}(\mathrm{OH})_{3}$ (2-line ferrihydrite), 7 - $\mathrm{Fe}(\mathrm{OH})_{3}$ (6-line ferrihydrite).

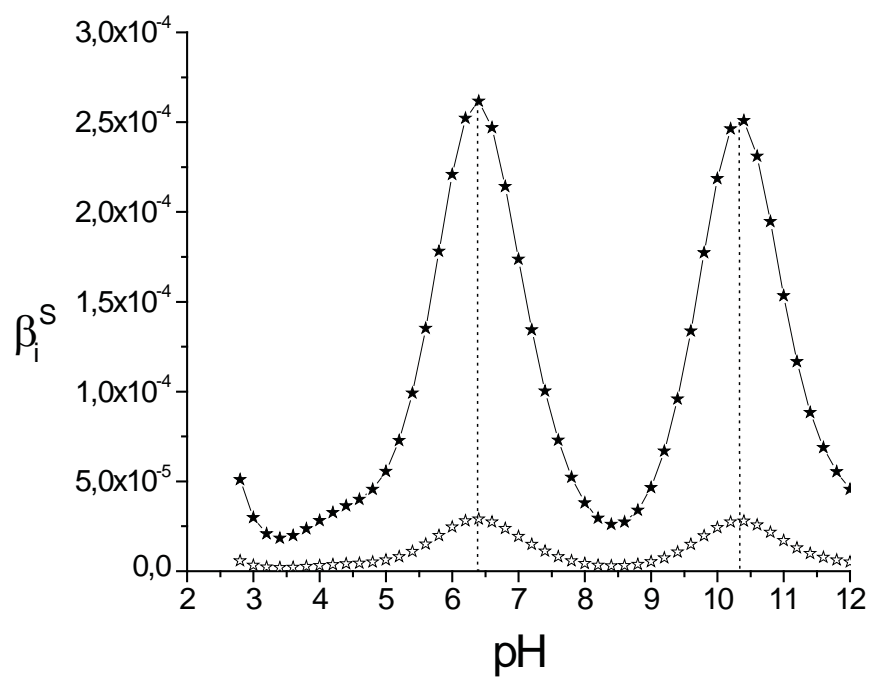

Figure 3. Buffer capacities $\beta_{H}^{S}$ (1) and $\beta_{F e}^{S}$ (2) versus $\boldsymbol{p H}$ for the system "Hematite - saturated aqueous solution".

The used concentrations $\left(\mathrm{mol} \mathrm{L}^{-1}\right): \mathrm{C}_{\mathrm{Fe}}^{0}=1 \cdot 10^{-5}, \mathrm{C}_{\mathrm{F}}^{0}=5 \cdot 10^{-6}, \mathrm{C}_{\mathrm{Org}}^{0}=\mathrm{C}_{\mathrm{PO}_{4}}^{0}=\mathrm{C}_{\mathrm{SO}_{4}}^{0}=1 \cdot 10^{-4}, \mathrm{C}_{\mathrm{CO}_{3}}^{0}=1 \cdot 10^{-3}$.

The iron (III) ions and its complexes have a significant contribution only in very acidic solutions up to $p H 4.5$. The analysis of the data presented in Figures 2 and 3 allows us to conclude that the studied heterogeneous system has a buffer capacity in relation to ions of hydrogen and iron (III). We will note down that these relations are valid only in the presence of solid phases.

Another example of real natural system that we examined is "Gibbsite - saturated aqueous solution". By increasing the acidity in aqueous solutions the content of aluminium grows quickly due to the interaction of the gibbsit with an acid:

$\mathrm{Al}(\mathrm{OH})_{3(\mathrm{~S})}+3 \mathrm{H}^{+}=\mathrm{Al}^{3+}+3 \mathrm{H}_{2} \mathrm{O}, \mathrm{K}_{S}=\left[\mathrm{Al} \mathrm{l}^{3+}\right]\left[\mathrm{H}^{+}\right]^{-3}$

An important interrelation between the buffer capacities of the heterogeneous system "Gibbsite $\mathrm{Al}(\mathrm{OH})_{3(\mathrm{~s})}$ - saturated aqueous solution" system can be identified [53,54]:

$\beta_{H}^{S}=9 \beta_{A l}^{S}$ 
Besides the process of gibbsite dissolution, a set of possible equilibria in the system "Mineral phase - natural water", listed in Table 2 has been taken into account [52]. The following composition of the heterogeneous system has been used for the calculations: $C_{A l}^{0}=1 \cdot 10^{-4} \mathrm{~mol} \mathrm{~L}^{-1}, C_{F}^{0}=5 \cdot 10^{-6} \mathrm{~mol} \mathrm{~L}^{-1}, C_{O r g}^{0}=1 \cdot 10^{-4} \mathrm{~mol} \mathrm{~L}^{-1}, C_{P O_{4}}^{0}=1 \cdot 10^{-4} \mathrm{~mol} \mathrm{~L}^{-1}$, $C_{\mathrm{SO}_{4}}^{0}=1 \cdot 10^{-4} \mathrm{~mol} \mathrm{~L}^{-1}$ and $C_{\mathrm{CO}_{3}}^{0}=1 \cdot 10^{-3} \mathrm{~mol} \mathrm{~L}^{-1}$. One can state that the influence of $H^{+}$in the studied $\mathrm{pH}$ interval may be neglected, and the $\mathrm{OH}^{-}$ions exercise influence on $\beta_{H}^{S}$ only at $p H>8.5$. The aluminium ions and their hydroxocomplexes make a significant contribution in acid solutions up to $p H 5.5$ and at $\mathrm{pH}>8$ because of the predominance of the stable anionic hydroxocomplex $\mathrm{Al}(\mathrm{OH})_{4}$. The results of the calculations of the buffer capacities $\beta_{H}^{S}$ as a function of $p H$ for different compositions of the heterogeneous mixture are shown in Figures 4-5. Obviously, an increase of the total concentration $C_{A l}^{0}$ (Figure 4) augments the area of the buffer action because of the extension of the $\mathrm{pH}$ interval of the thermodynamic stability of the solid phase. At concentrations of fluoride $C_{F}^{0}=5 \cdot 10^{-4} \mathrm{~mol} \mathrm{~L}^{-1}$, the $\beta_{H}^{S}$ value increases sharply in the range of $\mathrm{pH}$ values of the gibbsite dissolution - formation with a simultaneous narrowing of the total $p H$ range of the buffer action (Figure 5).

Table 2

\section{Equilibrium constants and values of enthalpies $(\Delta H)$.}

\begin{tabular}{|c|c|c|}
\hline Equations of reactions & $\log K$ & $\Delta H\left(\mathrm{cal} \mathrm{mol}^{-1}\right)$ \\
\hline $\mathrm{Al}^{3+}+\mathrm{H}_{2} \mathrm{O}=\mathrm{AlOH} \mathrm{H}^{2+}+\mathrm{H}^{+}$ & -4.99 & 11900 \\
\hline$A l^{3+}+2 \mathrm{H}_{2} \mathrm{O}=\mathrm{Al}(\mathrm{OH})_{2}^{+}+2 \mathrm{H}^{+}$ & -10.00 & 22000 \\
\hline$A l^{3+}+4 \mathrm{H}_{2} \mathrm{O}=\mathrm{Al}(\mathrm{OH})_{4}^{-}+4 \mathrm{H}^{+}$ & -23.00 & 44060 \\
\hline $\mathrm{Al}(\mathrm{OH})_{3(\mathrm{~S})}+3 \mathrm{H}^{+}=\mathrm{Al} l^{3+}+3 \mathrm{H}_{2} \mathrm{O}$ & 9.35 & -22800 \\
\hline$A l^{3+}+F^{-}=A l F^{2+}$ & 7.02 & 1100 \\
\hline$A l^{3+}+2 F^{-}=A l F_{2}^{+}$ & 12.76 & 2000 \\
\hline$A l^{3+}+3 F^{-}=A l F_{3}$ & 17.03 & 2500 \\
\hline$A l^{3+}+4 F^{-}=A l F_{4}^{-}$ & 19.73 & 2200 \\
\hline$A l^{3+}+5 F^{-}=A l F_{5}^{2-}$ & 20.92 & 1800 \\
\hline $\mathrm{Al}^{3+}+\mathrm{SO}_{4}^{2-}=\mathrm{AlSO}_{4}^{+}$ & 3.01 & 2150 \\
\hline $\mathrm{Al}^{3+}+2 \mathrm{SO}_{4}^{2-}=\mathrm{Al}\left(\mathrm{SO}_{4}\right)_{2}^{-}$ & 4.90 & 2840 \\
\hline $\mathrm{Al}^{3+}+\mathrm{Org}^{3-}=\mathrm{AlOrg}$ & 8.39 & - \\
\hline $\mathrm{Al}^{3+}+\mathrm{H}^{+}+\mathrm{Org}^{3-}=\mathrm{AlHOrg}^{+}$ & 13.09 & - \\
\hline $\mathrm{Org}^{3-}+\mathrm{H}^{+}=\mathrm{HOrg}^{2-}$ & 6.83 & - \\
\hline $\mathrm{Org}^{3-}+2 \mathrm{H}^{+}=\mathrm{H}_{2} \mathrm{Org}^{-}$ & 12.73 & - \\
\hline $\mathrm{Org}^{3-}+3 \mathrm{H}^{+}=\mathrm{H}_{3} \mathrm{Org}$ & 14.49 & - \\
\hline$H^{+}+F^{-}=H F$ & 3.17 & 3460 \\
\hline $\mathrm{H}_{2} \mathrm{O}=\mathrm{H}^{+}+\mathrm{OH}^{-}$ & -14.00 & 13340 \\
\hline $2 \mathrm{Al}^{3+}+2 \mathrm{H}_{2} \mathrm{O}=\mathrm{Al}_{2}(\mathrm{OH})_{2}^{4+}+2 \mathrm{H}^{+}$ & -6.3 & - \\
\hline $3 \mathrm{Al}^{3+}+4 \mathrm{H}_{2} \mathrm{O}=\mathrm{Al}_{3}(\mathrm{OH})_{4}^{5+}+4 \mathrm{H}^{+}$ & -12.1 & - \\
\hline$A l^{3+}+H_{2} P O_{4}^{-}=A l H_{2} P O_{4}^{2+}$ & 3.1 & - \\
\hline $\mathrm{PO}_{4}^{3-}+\mathrm{H}^{+}=\mathrm{HPO}_{4}^{2-}$ & 12.0 & - \\
\hline $\mathrm{PO}_{4}^{3-}+2 \mathrm{H}^{+}=\mathrm{H}_{2} \mathrm{PO}_{4}^{-}$ & 19.21 & - \\
\hline $\mathrm{PO}_{4}^{3-}+3 \mathrm{H}^{+}=\mathrm{H}_{3} \mathrm{PO}_{4}$ & 21.36 & - \\
\hline
\end{tabular}

Note: $1 \mathrm{cal}=4.184 \mathrm{~J}$, Org - organic ligand, the „-— specifies the absence of experimental data. 


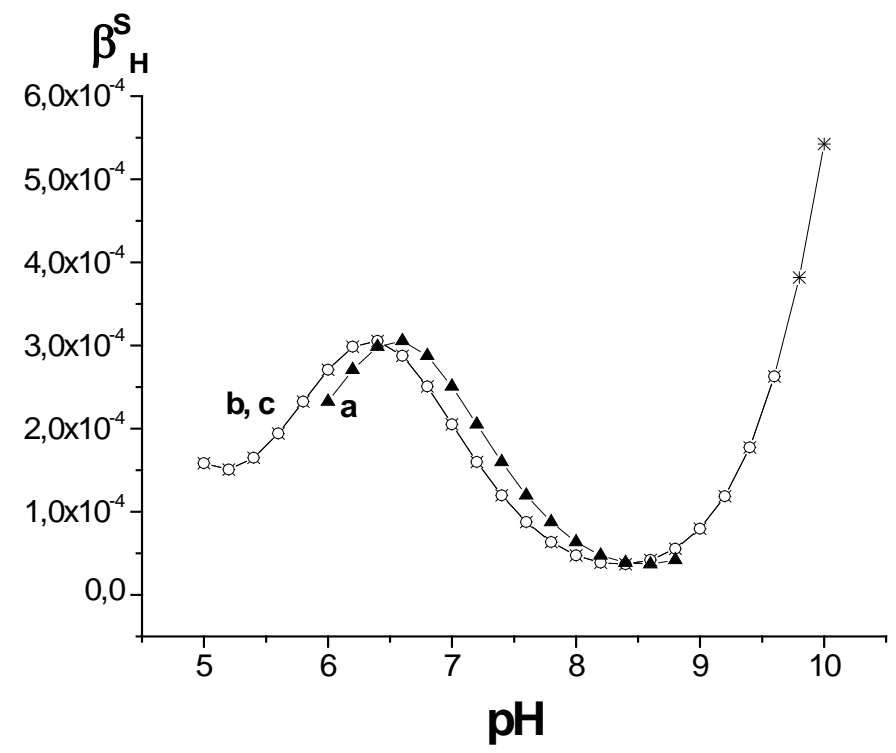

Figure 4. Buffer capacity $\beta_{H}^{S}$ versus $p H$ for the "Gibbsite - saturated aqueous solution" system. Concentrations $\left(\mathrm{mol} \mathrm{L}^{-1}\right)$ :

$\mathrm{C}_{\mathrm{Al}}^{0}: \mathrm{a}-1 \cdot 10^{-3}, \mathrm{~b}-1 \cdot 10^{-4}, \mathrm{c}-1 \cdot 10^{-5}, \mathrm{C}_{\mathrm{F}}^{0}=\mathbf{5} \cdot 10^{-6}, \mathrm{C}_{\mathrm{Org}}^{0}=\mathrm{C}_{\mathrm{PO}_{4}}^{0}=\mathrm{C}_{\mathrm{SO}_{4}}^{0}=1 \cdot 10^{-4}, \mathrm{C}_{\mathrm{CO}_{3}}^{0}=1 \cdot 10^{-3}$.

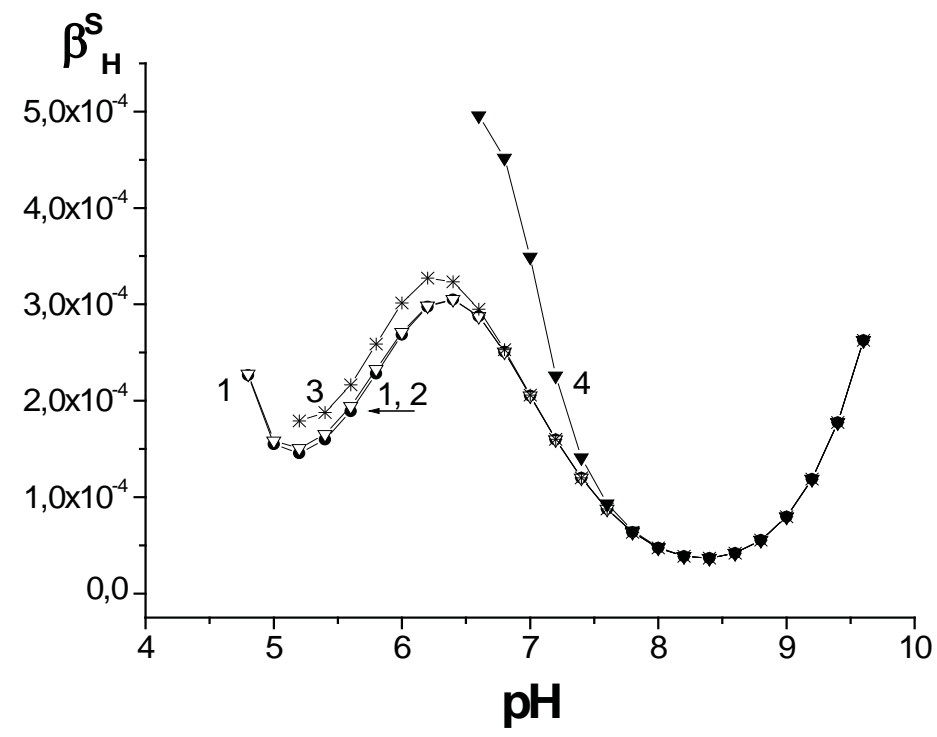

Figure 5. Buffer capacity $\beta_{H}^{S}$ versus $p H$ for the "Gibbsite - saturated aqueous solution" system. Concentrations $\left(\mathrm{mol} \mathrm{L}^{-1}\right)$ :

$\mathrm{C}_{\mathrm{F}}^{0}: 1-5 \cdot 10^{-7}, 2-5 \cdot 10^{-6}, 3-5 \cdot 10^{-5}, 4-5 \cdot 10^{-4}, \mathrm{C}_{\mathrm{Al}}^{0}=\mathrm{C}_{\mathrm{Org}}^{0}=\mathrm{C}_{\mathrm{PO}_{4}}^{0}=\mathrm{C}_{\mathrm{SO}_{4}}^{0}=1 \cdot 10^{-4}, \mathrm{C}_{\mathrm{CO}_{3}}^{0}=1 \cdot 10^{-3}$.

The dependences of $\beta_{H}^{S}(\mathrm{pH})$ for different concentrations of carbonate ion are presented in Figure 6. By taking into account the contribution of equilibria including carbonate ion in the total buffer capacity $\beta_{\mathrm{H}}^{S}$, the $\beta_{\mathrm{CO}_{3}}^{\mathrm{H}}$ value was calculated separately. A comparison of the calculated curves shows that equilibria with $\mathrm{CO}_{3}^{2-}$ participation have a substantial contribution to $\beta_{H}^{S}$ at a $C_{\mathrm{CO}_{3}}^{0}>1 \cdot 10^{-4} \mathrm{~mol} \mathrm{~L}^{-1}$ (Figures $7 \mathrm{a}$ and $7 \mathrm{~b}$ ). The analysis of the obtained data 
presented in Figures 4-7, taking into account Eq.(33) allows us to conclude that the investigated heterogeneous system has a considerable buffer capacity towards to aluminium as well.

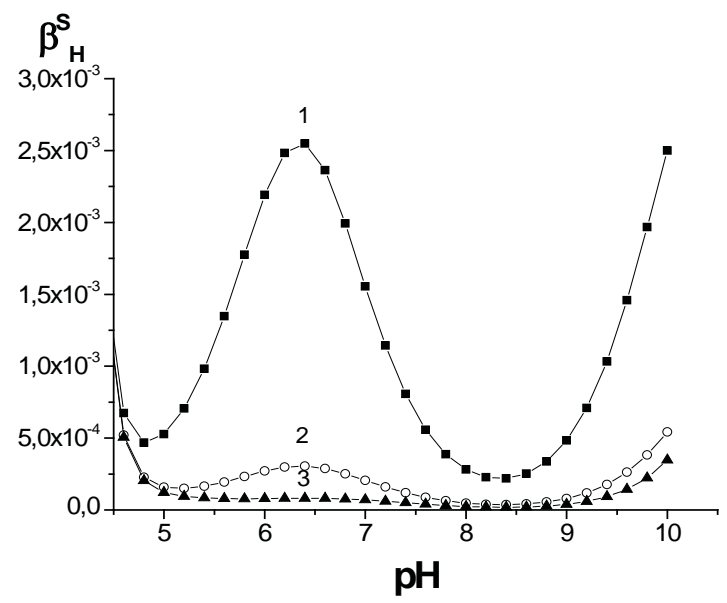

Figure 6. Buffer capacity $\beta_{H}^{S}$ versus $\mathrm{pH}$ for the "Gibbsite - saturated aqueous solution" system. Concentrations $\left(\mathrm{mol} \mathrm{L}^{-1}\right)$ :

$$
\mathrm{C}_{\mathrm{CO}_{3}}^{0}: 1-1 \cdot 10^{-2}, 2-1 \cdot 10^{-3}, 3-1 \cdot 10^{-4}, \mathrm{C}_{\mathrm{Al}}^{0}=\mathrm{C}_{\mathrm{PO}_{4}}^{0}=\mathrm{C}_{\mathrm{SO}_{4}}^{0}=1 \cdot 10^{-4}, \mathrm{C}_{\mathrm{F}}^{0}=5 \cdot 10^{-6} \text {. }
$$
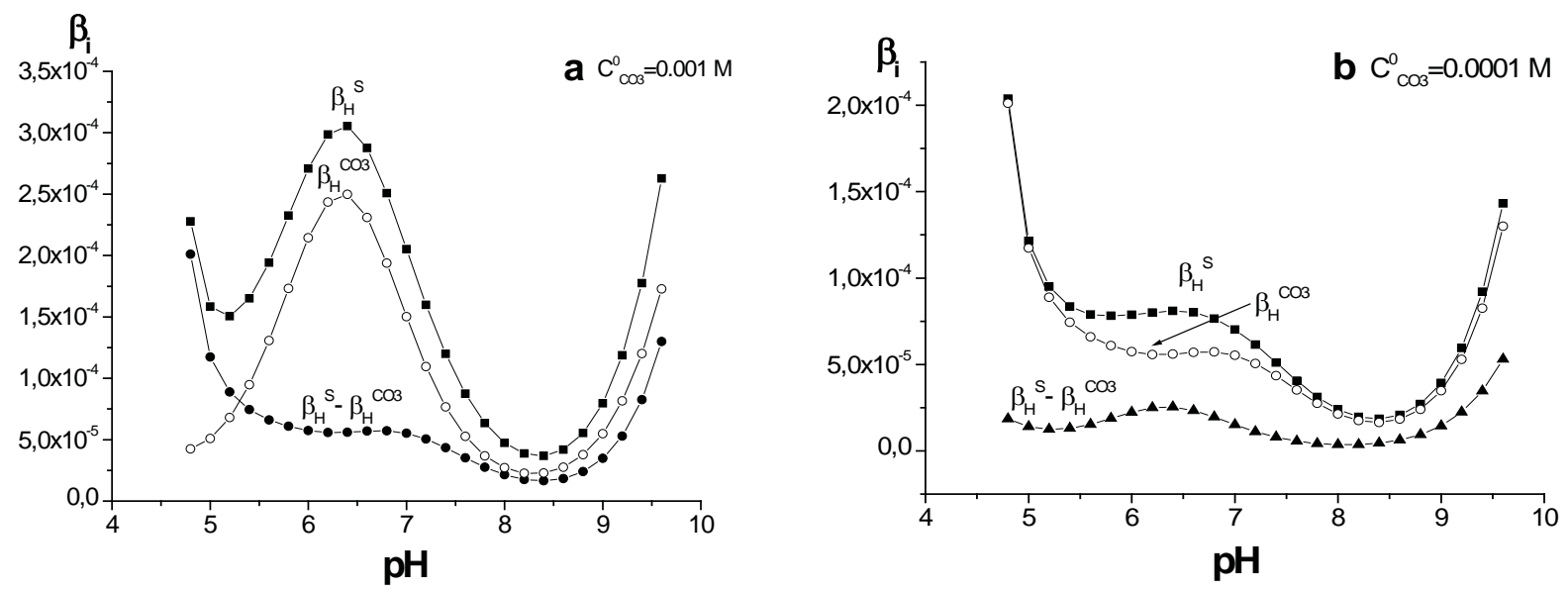

Figure 7. Total buffer capacity $\beta_{\mathrm{H}}^{S}$ versus $\boldsymbol{p H}$, carbonate buffer capacity $\beta_{\mathrm{CO}}^{\mathrm{H}}$ vs. $\mathrm{pH}$ and their difference $\beta_{H}^{S}-\beta_{C O_{3}}^{H}$ for the "Gibbsite - saturated aqueous solution" system.

Concentrations $\left(\mathrm{mol} \mathrm{L}^{-1}\right): \mathrm{C}_{\mathrm{CO}_{3}}^{0}: \mathbf{a}-1 \cdot 10^{-3}, \mathrm{~b}-1 \cdot 10^{-4}, \mathrm{C}_{\mathrm{Al}}^{0}=\mathrm{C}_{\mathrm{PO}_{4}}^{0}=\mathrm{C}_{\mathrm{SO}_{4}}^{0}=1 \cdot 10^{-4}, \mathrm{C}_{\mathrm{F}}^{0}=5 \cdot 10^{-6}$.

The influence of temperature on the value of the buffer capacity was also studied [55]. The results of the calculations are presented in Figure 8. The equilibrium constants for different temperatures have been estimated by the Van't Hoff equation.

$$
\log K_{2}=\log K_{1}+\left(1 / T_{1}-1 / T_{2}\right) \Delta H / 2.303 R
$$

The necessary values of enthalpies $(\Delta H)$ are listed in Table 2. $T_{1}$ was set to $298 \mathrm{~K}=25^{\circ} \mathrm{C}$. It was assumed that the temperature insignificantly influences the $\Delta H$ values inside the investigated temperature range. An analysis of the curves in Figure 8 shows that the buffer capacity increases with a temperature decrease, whereas the $p H$ interval of $5.5-7.0$ of the maximum values of the buffer capacity displaces slightly. 


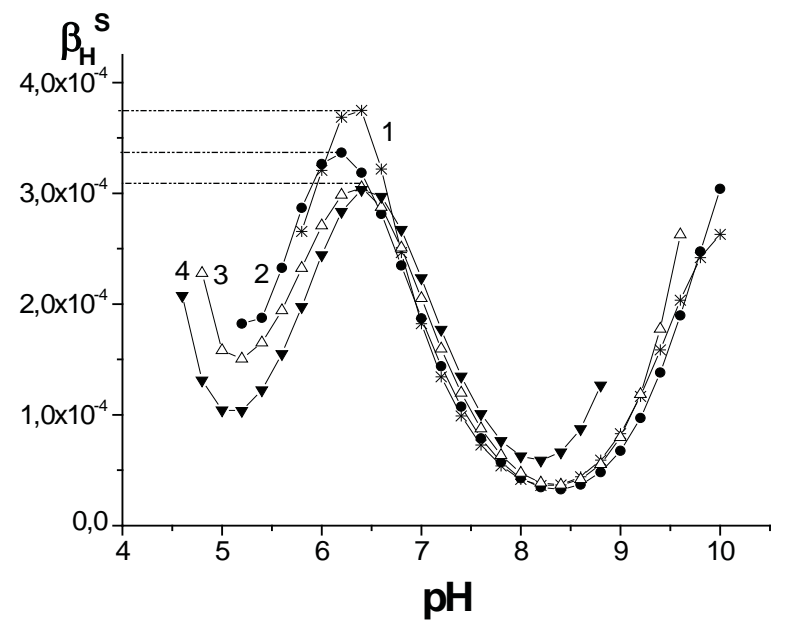

Figure 8. Buffer capacity $\beta_{H}^{S}$ versus $\mathrm{pH}$ for the "Gibbsite - saturated aqueous solution" system at different temperatures $\left(t,{ }^{\circ} \mathrm{C}\right):(1)-5,(2)+10,(3)+25$ and $(4)+40$.

Concentrations $\left(\mathrm{mol} \mathrm{L}^{-1}\right): \mathbf{C}_{\mathrm{CO}_{3}}^{0}=\mathbf{1} \cdot \mathbf{1 0}^{-3}, \mathrm{C}_{\mathrm{Al}}^{0}=\mathbf{C}_{\mathrm{PO}_{4}}^{0}=C_{O r g}^{0}=\mathbf{C}_{\mathrm{SO}_{4}}^{0}=\mathbf{1} \cdot \mathbf{1 0}^{-4}, \mathrm{C}_{\mathrm{F}}^{0}=\mathbf{5} \cdot \mathbf{1 0}^{-6}$.

\section{Buffer properties for liquid two-phase acid-base buffer systems}

Buffer with mono- and diprotic acids

The theoretically calculated and experimentally measured dependences of the buffer capacity on $p H$ in the case of two-phase system 1-octanol - water for monoprotic $n$-hexanoic acid and diprotic 1,2-benzenedicarboxylic acid are shown in Figure 9 and Figure 10, respectively. Experimental data $[45,56]$ were obtained at $25^{\circ} \mathrm{C}$ and constant ionic strength. For both systems, the experimental data correlate well with the theoretical curves, calculated by Eqs.(27 - 28) that confirms their correctness. The values in Figures 9 and 10 testify the validity of Eq.(29). (The necessary equilibrium constants were taken from $[45,56]$.)

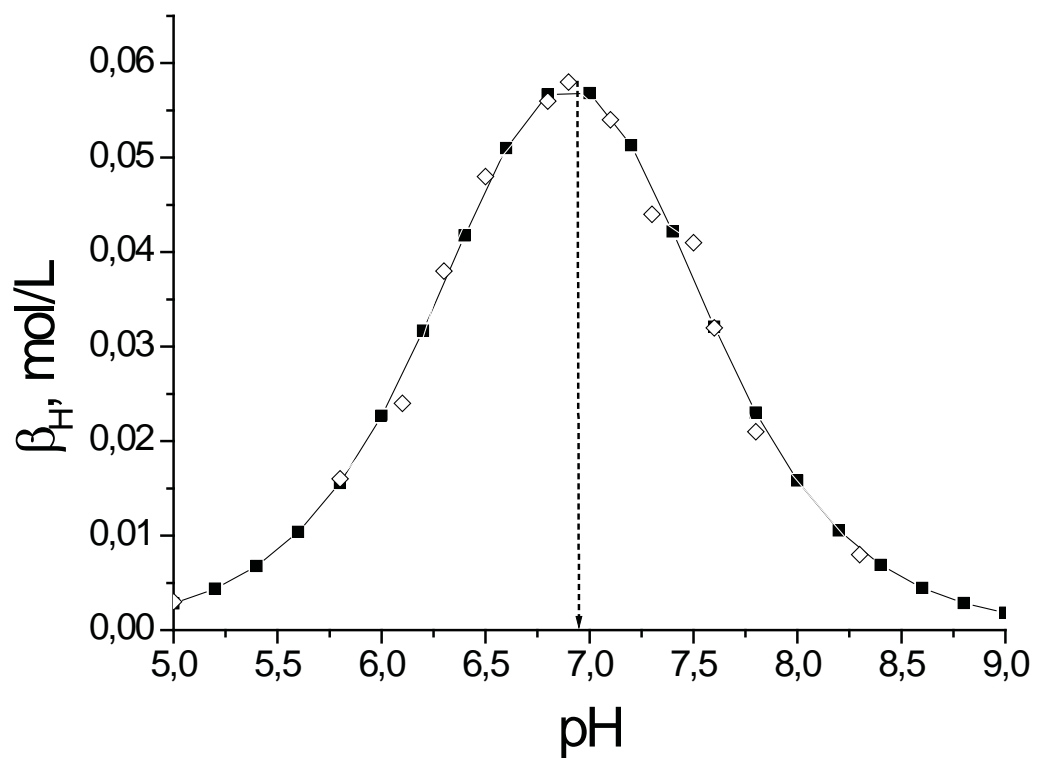

Figure 9. Buffer capacity versus $p H$ for two-phase system containing n-hexanoic acid $H A$ and 1-octanol:

$(\square)$ the calculated values; $(\diamond)$ experimental data [56];

1-octanol : water $=1: 1 ; C_{A}^{0}=\mathbf{0 . 1} \mathrm{mol} \mathrm{L}^{-1}, \mathbf{I}=\mathbf{0}, \mathbf{t}=25^{\circ} \mathrm{C}$. 


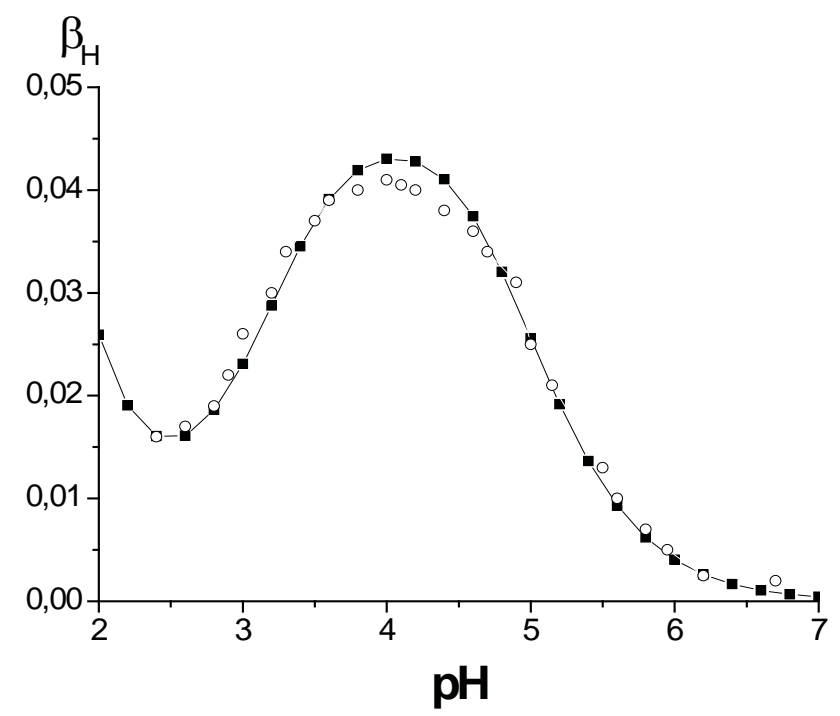

Figure 10. Dependence of buffer capacity on $\mathrm{pH}$ for two-phase system containing 1,2-benzenedicarboxylic acid and 1-octanol: $(\square)$ calculated values; $(\circ)$ experimental data [45];

1-octanol : water $=1: 1 ; C_{A}^{0}=0.0488 \mathrm{~mol} \mathrm{~L}^{-1}, \mathrm{I}=1(\mathrm{NaCl}), \mathrm{t}=25^{\circ} \mathrm{C}$.

Two-phase buffers with monoprotic acids in which dimerization occurs

Mono-component systems: propanoic acid - water - benzene (I) and decanoic acid - water - benzene (II):

The numerical values of the equilibrium constants used for calculating the theoretical buffer curves as well as the experimental data were taken from [56]. The theoretical and experimental data are presented in Figure 11 (a,b). It can be seen that the theoretical curves are in good agreement with experimental values.

$a$

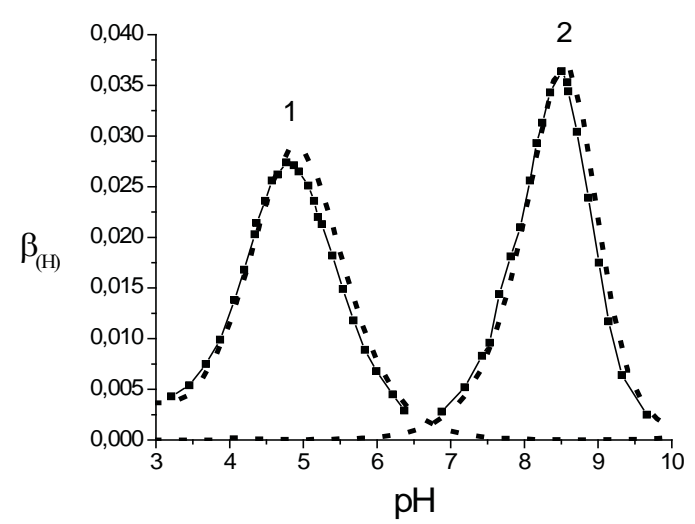

$b$

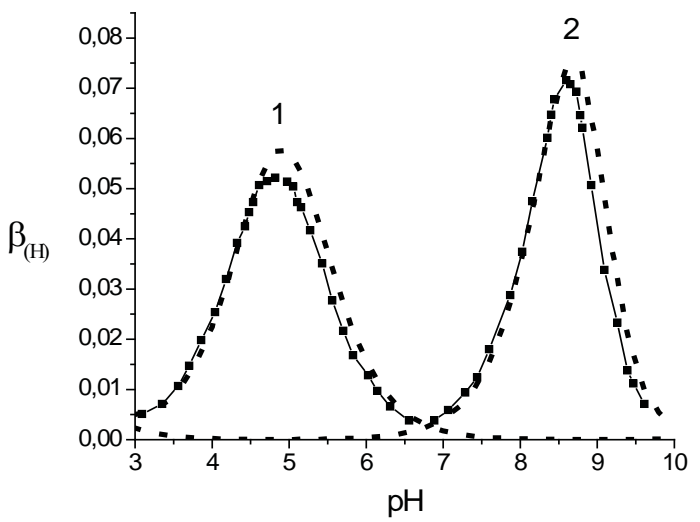

Figure 11. Buffer capacity $\beta_{H}$ versus $p H$ for mono-component two-phase systems with propanoic (a) and decanoic (b) acids, $C_{A}^{0}=0.05 \mathrm{~mol} \mathrm{~L}^{-1}$ (a) and $C_{A}^{0}=0.1 \mathrm{~mol} \mathrm{~L}^{-1}$ (b) and $\alpha=1$;

(a) - experimental values, dotted lines - experimental curves, $\mathrm{I}=0.1, \mathrm{t}=25^{\circ} \mathrm{C}$.

On Figure 12 the functional dependence $\beta_{H}=f(p H)$ for (2.4-dichlorophenoxy)acetic acid for aqueous solution and two-phase mixture by means of different organic solvents is graphically illustrated. One can see that high $\beta_{H}$ values within a large $p H$ range $(3.75 \div 5.75)$ can be assured by using different organic solvents [57]. The necessary equilibrium data were taken from [58]. 


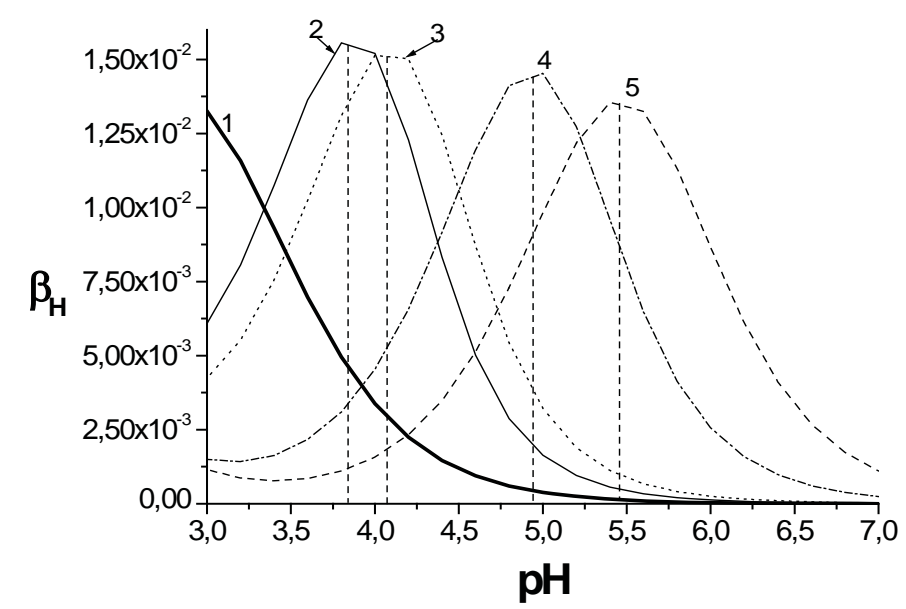

Figure 12. Buffer capacity $\beta_{H}$ versus $p H$ for mono-component two-phase systems with (2.4-dichlorophenoxy) acetic acid, $C_{A}^{0}=0.05 \mathrm{~mol} \mathrm{~L}^{-1}, \alpha=1, t=25^{\circ} \mathrm{C}$ for different organic solvents:

1 - no solvent; 2 - ethylbenzene; 3 - 1-octanol; 4 - chlorbenzene; 5 - nitrobenzene.

pH and $p A$ buffer properties of two-component system in which mixed dimmer occurs

The authors [56] found that the rule of additivity for calculating the total buffer capacity as a sum of separate contributions for this system is not valid. As a result, there are some substantial deviations of the theoretical curves from experimental data within the interval of $\mathrm{pH}$ from 4 to 7 . The experimental data for this system, along with the calculated theoretical curve are presented in Figure 13. As one can see, the experimental values $\beta_{H}=f(p H)$ are in good agreement with those calculated, contrasting to the results received by authors [56]. Thus, the experiment confirms the validity of our developed theoretical approach.

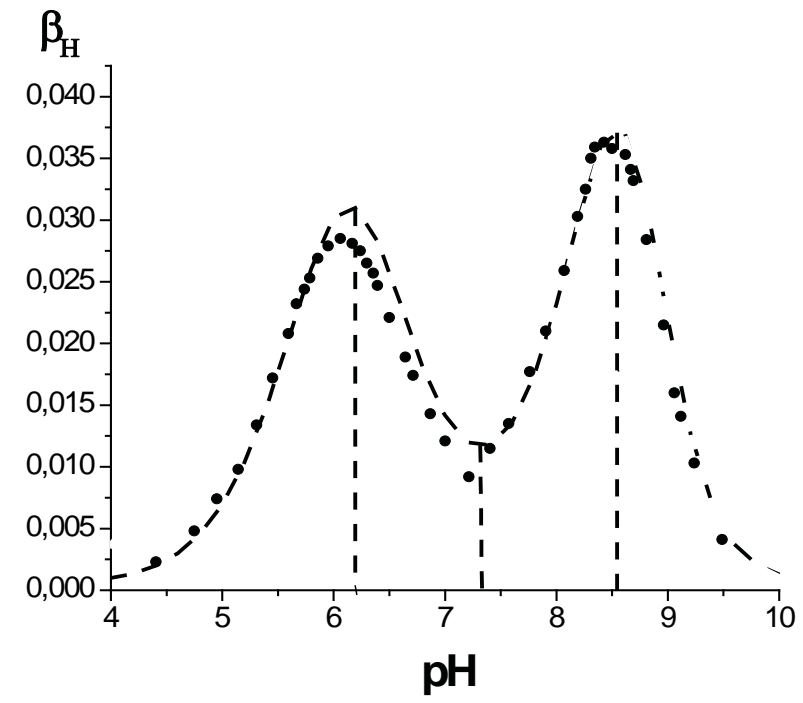

Figure 13. Experimental data [56] (•) and calculated values (---) for $\beta_{H}(p H)$ as a sum of the contributions of separate acids for the two-component two-phase buffer system containing hexanoic and decanoic acids. $\mathbf{V}\left(\mathbf{C}_{\mathbf{6}} \mathbf{H}_{\mathbf{6}}\right) \div \mathbf{V}\left(\mathbf{H}_{\mathbf{2}} \mathbf{O}\right)=\mathbf{1} \div \mathbf{1}, C_{A}^{0}=C_{B}^{0}=\mathbf{0 . 0 5} \mathrm{mol} \mathrm{L}^{-1}, \mathbf{I}=\mathbf{0 . 1}, \mathbf{t}=25^{\circ} \mathrm{C}$.

In Figure 14 the curves of dependences $\beta_{H}=f(p H), \beta_{A}=f(p H)$ and $\beta_{B}=f(p H)$ are presented. From here it is possible to conclude, that the buffer capacity of two-phase mixtures containing an acid capable to form homogeneous and mixed dimers in the organic solvent, is much higher with respect to anions, than to proton, i.e. $\beta_{A}\left(\beta_{B}\right)>\beta_{H}$. At the same time, the maximum value of both functions is registered in the conditions of predominance of the un-bonded anion in aqueous phase. 


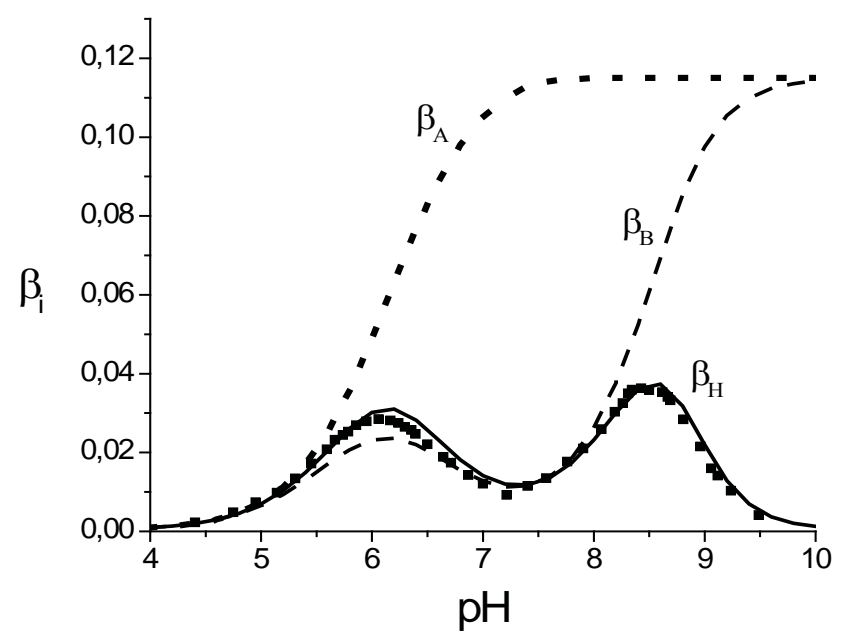

Figure 14. Curves $\beta_{H}=f(p H), \beta_{A}=f(p H)$ and $\beta_{B}=f(p H)$ for the two-component two-phase buffer system,

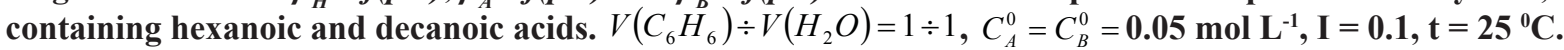

On Figure15 the functional dependence $\beta_{A}=f(p A)$ for (2.4-dichlorophenoxy)acetic acid for aqueous solution and water-1-octanol mixture is depicted. One can notice that the presence of organic solvent amplifies significantly (approximately by 70 times) the $\beta_{A}$ value at $p A=5.4$. Therefore, two-phase mixtures can be successfully used for designing new buffers with respect to any component for investigated systems. The developed approach can be expanded to other, more complicated systems, containing metal-ligand complexes.

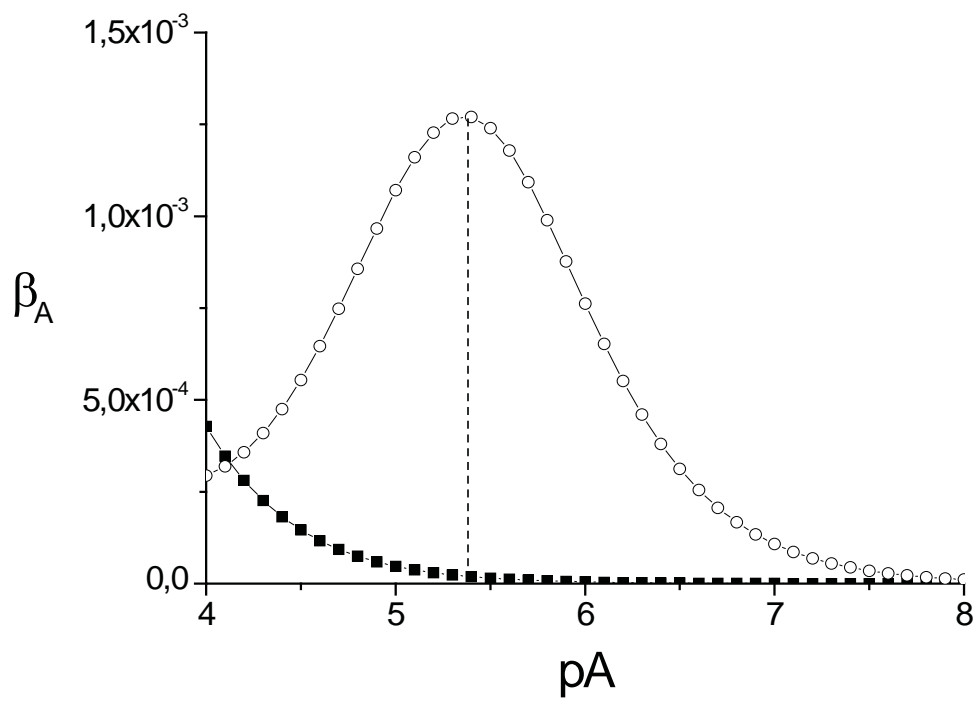

Figure 15. Buffer capacity $\beta_{A}$ versus $p A$ for the mono-component system with (2.4-dichlorophenoxy) acetic acid in water (curve 1) and water-1-octanol mixture (curve 2), $C_{H}^{0}=0.005 \mathrm{~mol} \mathrm{~L}^{-1}, \alpha=1 ; \mathrm{t}=25{ }^{0} \mathrm{C}$.

\section{Conclusions}

The analyzed heterogeneous systems manifest buffer actions towards protons, cations or anions of weak bases or acids. The deduced analytical expressions for buffer capacities in respect to all ions of distributed species between two immiscible liquids are reported. For all investigated systems a relation of proportionality between buffer capacities is found. On the basis of the analysis of found identities it can be concluded that it is sufficient to measure only the $\beta_{H}$ value, while the quantity $\beta_{A}$ can be calculated from a set of expressions identities derived in this work. This conclusion is especially valuable since for the $\beta_{H}$ measurement it is necessary to determine potentiometrically the $p H$ values while for the $\beta_{A}$ determination it is required to measure the $p A=-\log [A]$ values. It is known, that the $\mathrm{pH}$-metric method is 
much more precisely and does not require special ion-selective electrodes as for $p A$ measurement, which have been developed so far only for a few number of anions. The experimental evidence completely confirms the validity of the derived equations. The relation of proportionality between the buffer capacities in respect to all ions of the species distributed between phases has been also found for the heterogeneous systems of the type "Solid phase-saturated aqueous solution", which serves as a proof of the generality of this phenomenon. It is demonstrated that the $p H_{\max }$ value of the maximal buffer capacity shifts for two-phase system in comparison with classical aqueous buffer mixtures by $\log (1+P(H A))$ which depends mainly on the nature of organic solvent. Also, it has been explained the nature of synergic effect of the total buffer action of heterogeneous mixtures. Generally, the mixture of acids and bases shows a cumulative effect, but in the case of interaction of distributed species in the organic phase, it manifests a synergic effect, e.g. the buffer action amplifies It is finally worth noting that heterogeneous buffer systems can be created on the basis of wellknown species and do not require any special installations. The deduced relations may be used for search and design of new ion-molecular two-phase buffers with required properties. Owing to the described properties, the considered heterogeneous systems can find widespread use in various areas of chemical and biochemical researches, especially in analytical chemistry, pharmacology, pharmaceutics, medical industry and synthetic organic chemistry.

\section{References}

1. Roy, R.N.; Roy, L.N.; Stegner, J.M.; Sechler, S.A.; Jenkins, A.L.; Krishchenko, R.; Henson, I.B. Buffer standards for the physiological $\mathrm{pH}$ of N, N - bis (2- hydroxyethyl) - 2-aminoethanesulfonic acid (BES) from (278.15 to 328.15) K. Electroanalytical Chemistry, 2011, 663, pp. 8-13.

2. Dolejs, D.; Wagner, T. Thermodynamic modeling of non-ideal mineral-fluid equilibria in the system Si-Al-Fe$\mathrm{Mg}-\mathrm{Ca}-\mathrm{Na}-\mathrm{K}-\mathrm{H}-\mathrm{O}-\mathrm{Cl}$ at elevated temperatures and pressures: Implications for hydrothermal mass transfer in granitic rocks. Geochimica and Cosmochimica Acta, 2008, 72, pp. 526-553.

3. Roy, L.N.; Roy, R.N.; Wollen, J.T.; Harmon, M.A.; Stegner, J.M.; Shah, A.A.; Henson, I.B. Buffer standards for the biological $\mathrm{pH}$ of the amino acid $\mathrm{n}$ - [2 - hydroxyethyl] piperazine-n' - [3 - propanesulfonic acid], HEPPS, from (278.15 to 328.15) K. Journal of Chemical and Engineering Data, 2011, 56, pp. 4126-4132.

4. Kay, J.W.; Steven, R.J.; McGuigan, J.A. S.; Elder, H.Y. Automatic determination of ligand purity and apparent dissociation constant $\left(\mathrm{K}_{\text {app }}\right)$ in $\mathrm{Ca}^{2+} / \mathrm{Mg}^{2+}$ buffer solutions and the $\mathrm{K}_{\text {app }}$ for $\mathrm{Ca}^{2+} / \mathrm{Mg}^{2+}$ anion binding in physiological solutions from $\mathrm{Ca}^{2+} / \mathrm{Mg}^{2+}-$ macroelectrode measurements. Computers in Biology and Medicine, 2008, 38, pp. 101-110.

5. Totsche, O.; Fyson, A.; Kalin, M.; Steinberg, C.E.W. Titration Curves: A useful instrument for assessing the buffer systems of acidic mining waters. Environmental Science and Pollution Research, 2006, 13, pp. 215-224.

6. Dougherty, D.P.; Neta, C.E.; McFeeters, R.F.; Lubkin, S.R.; Breidt, F.J. Semi-mechanistic partial buffer approach to modelling $\mathrm{pH}$, the buffer properties, and the distribution of ionic species in complex solutions. Journal of Agricultural and Food Chemistry, 2006, 54, pp. 6021-6029.

7. Upadhyay, N.; Majestic, B.J.; Herckes, P. Solubility and speciation of atmospheric iron in buffer systems simulating cloud conditions. Atmospheric Environment, 2011, 45, pp. 1858-1866.

8. Perrin, D.D.; Dempsey B. Buffers for pH and metal ion control. Chapman and Hall: London, 1974, 175 p.

9. Komari, N.P. Chemical metrology. Ionic heterogeneous equilibria. Vishcha Shkola: Kharkov, 1984, 208 p. (in Russian).

10. Povar, I. On homogeneous ion buffer systems. Russian Journal of Inorganic Chemistry, 2000, 45(10), pp. 1628-1631.

11. Povar, I.; Spinu, O. On the theory of homogeneous metal-ligand buffers. Abstracts of communications of The International Conference dedicated to the 55th anniversary from the foundation of the Institute of Chemistry of the Academy of Sciences of Moldova. Chisinau, Moldova, May 28-30, 2014, p. 174.

12. Charykov, A.K.; Osipov N.N. Carbonic acids and carboxylate complexes in chemical analysis. Khimia: Leningrad, 1991, pp. 204-207 (in Russian).

13. Pfendt, L.B. Two-phase liquid and solid-liquid $\mathrm{pH}$ buffers based on solubility equilibria: Theoretical considerations. Analyst, 1995, 120, pp. 2129-2144.

14. Povar, I.; Rusu, V. Buffer capacity of heterogeneous chemical equilibria in natural waters. Canadian Journal of Chemistry, 2012, 90, pp. 395-402.

15. Fishtik, I.; Povar, I. Buffer Capacity in Multiple Chemical Reaction Systems Involving Solid Phases. Canadian Journal of Chemistry, 2006, 84, pp. 1036-1044.

16. Povar, I. Buffering properties of heterogeneous water-salt systems in relation to the components of a low-solubility precipitate. Russian Journal of Inorganic Chemistry, 2000, 45, pp. $1632-1636$.

17. Povar, I. Method for graphic representation of heterogeneous chemical equilibria in systems sparingly soluble compound-complexing agent-aqueous solution. Russian Journal of Inorganic Chemistry, 1997, 42, pp. 607-612.

18. Povar, I.; Luca, C. Considerations regarding the ionic-molecular buffer solutions. Revue de Chimie, 2003, 54, pp. 312-316 (in Romanian). 
19. Povar, I.; Spinu, O. Quantitative theory of the buffer action of soil minerals. Collection of scientific papers of the Conference with International Participation "Chernozems of Moldova - development, protecting and restoring their fertility", dedicated to the 60th anniversary of the founding of the IPAPS "N.Dimo". Chisinau, Republic of Moldova, September 12-13, 2013, pp. 272-277.

20. Povar, I. Buffer properties of the system such as slightly soluble salt - saturated solution in respect to precipitate components. Abstracts of the XXII-th Session of Scientific Communications. Olanesti, Romania, 23-25 October, 1996, V. 2, pp. 685- 690 (in Romanian).

21. Spinu, O.; Povar, I. Relationships between buffer capacities of chemical components in heterogeneous natural systems. Book of Abstracts International Conference on Physical Chemistry (ROMPHYSCHEM 15). Bucharest, Romania, September 11-13, 2013, p. 153.

22. Van Breemen, N.; Wielemaker, W.G. Buffer intensities and equilibrium $\mathrm{pH}$ of minerals and soils: 1. The Contribution of minerals and aqueous carbonate to pH buffering. Soil Science Society of America Journal, 1974, 38, pp. 55-60.

23. Stumm, W.; Morgan, J.J. Aquatic Chemistry. 3rd Edition. Wiley: New York, 1995, 1040 p.

24. Filep, D.; Radly, M. The forms of acidity and acid-base buffer action of soils. Pedology, 1989, 12, pp. 48-59 (in Russian).

25. Lozovik, P.A.; Potapova, I. Yu.; Bantsevich, T.V. Buffer capacity of surface waters as a geochemical factor of their resistance to acidification. Geochemistry International, 2007, 45, pp. 938-944.

26. Langmuir, D. Aqueous Environmental Geochemistry. Prentice Hall: New Jersey, 1997, 600 p.

27. Poznyak, S.P.; Gamkalo, M.Z. Acid-base buffer action of Ukrainian Carpathians. Pedology, 2001, 6, pp. 660-669.

28. Sokolova, T.A.; Motuzova, G.V.; Malinina, M.S.; Obukhovskaya, T.D. Chemical basis of soil buffer action. MGU: Moscow, 1991, 106 p. (in Russian).

29. Povar, I.; Spinu, O. Buffer properties of soil minerals. Part.1 Theoretical Aspects. Chemistry Journal of Moldova, 2013, 8(2), pp. 67-72.

30. Povar, I.; Spinu, O. Buffer capacity of aquatic ecosystems as a geochemical factor of their resistance to pollution. Collected papers of the International Scientific Conference "Actual Problems of Search and Environmental Geochemistry". Kiev, Ukraine, July 1 - 2, 2014, pp. 94-96.

31. Povar, I.; Spinu, O. Thermodynamics of complex chemical equilibria in heterogeneous multicomponent systems. Printing House of the Academy of Sciences of Moldova: Chisinau, 2014, 452 p. (in Romanian).

32. Spinu, O.; Povar, I. Buffer properties of the system "calcium carbonate - soil solution". Collection of scientific papers of the Conference with International Participation "Chernozems of Moldova - development, protecting and restoring their fertility", dedicated to the 60th anniversary of the founding of the IPAPS "N.Dimo". Chisinau, Republic of Moldova, September 12-13, 2013, pp. 318-322.

33. Zaytseva T.F. The buffer action of soils and the questions of their diagnostic. Bulletin of Academy of Sciences of the USSR, Series of Biological Sciences, 1987, 14, pp. 69-80 (in Russian).

34. Samohvalova, V.; Spinu, O.; Povar, I. Buffering soil regarding the content of heavy metals. Collected articles of IX Congress of Soil Science and Agrochemistry. Nikolayev, Ukraine, June 30 - July 4, 2014, pp. 149-151.

35. Povar, I. Ion Buffer Capacity Approach as a tool for the Assessment of Long-Term Effects in Natural Attenuation/ Intrinsic Chemical Remediation of Metals in Contaminated Groundwaters, Soils and Sediments. Proceeding of the International Conference "Trans boundary River Basin Management and International Cooperation for Healthy Dniester". Odessa, Ukraine, 30 September - 1 October, 2009, pp. 215-219.

36. Spinu, O.; Povar, I. Use of the buffer capacity theory for evaluating the resistance of aquatic heterogeneous ecosystems to changes of metal contaminant levels. Book of Abstracts of International Symposium „The Environment and Industry" - SIMI. Bucharest, Romania, October 28-30, 2013, pp. 141-142.

37. Spinu, O.; Povar, I. Application of the buffer theory for natural remediation of ionic pollutants in aquatic ecosystems. Book of Abstracts of WASTE net 2015 Scientific Conference "Sustainable Solutions to Wastewater Management: Maximizing the Impact of Territorial Co-Operation". Kavalla, Greece, 19th - 21st June, 2015, p. 34.

38. Povar, I.; Spinu, O. The use of the buffer capacity theory for thermodynamic assessment of the natural control of heavy metal contents in polluted ecosystems. Book of abstracts of XIX International Conference on Chemical Thermodynamics RCCT-2013. Moscow, Russia, June 24-28, 2013, p. 53.

39. Povar, I. Methodology of Chemical Buffer Capacity Theory as an Instrument for Evaluating the Attenuation and Natural Remediation of Ionic Pollutants in Contaminated Aquatic Ecosystems. Proceeding of the International Symposium „The Environment and Industry” - SIMI. Bucharest, Romania, 28-30 October, 2009, pp. 315- 320.

40. Povar, I.; Rusu, V.; Spinu, O. Buffer capacity approach as a tool for assessing the fate of ionic pollutants in aquatic ecosystems. Abstracts of the V-th International Conference "Ecological Chemistry". Chisinau, Moldova, 2-3 March, 2012, p. 57.

41. Garcia-Gil, J.C.; Ceppi, S.B.; Velasco, M.I.; Polo, A.; Senesi, N. Long-term effects of amendment with municipal solid waste compost on the elemental and acidic functional group composition and pH-buffer capacity of soil humic acids. Geoderma, 2004, 121, pp. 135-142. 
42. Descourvières, C.; Niels, H.; Bradley, M.; Patterson, C. O.; Henning P. Geochemical controls on sediment reactivity and buffering processes in a heterogeneous aquifer. Applied Geochemistry, 2010, 25, pp. 261-275.

43. Povar, I. Thermodynamic calculation of the minimum solubility $\mathrm{pH}$ of slightly soluble oxides and hydroxides in polynuclear hydrolysis of metal ion. Ukrainian Chemical Journal, 1994, 60, pp. 371-378 (in Russian).

44. Povar I.; Rusu V. Aluminium heterogeneous speciation in natural waters. Canadian Journal of Chemistry, 2012, 90, pp. 326-332.

45. Janjic̈, T.J.; Milosavljević, E.B.; Nanayakkara, W.; Srdanovic, M. K. Two-phase buffer systems with diprotic acids. Analytica Chimica Acta, 1983, 152, pp. 229-237.

46. Povar, I.; Spinu, O. The influence of mixed dimmerization on buffering actions in two-phase liquid systems. Abstracts of communications of The International Conference dedicated to the 55th anniversary from the foundation of the Institute of Chemistry of the Academy of Sciences of Moldova. Chisinau, Moldova, May 28-30, 2014, p. 172.

47. Povar, I.; Spinu, O. How to amplify the buffer capacity by mixing organic solvents with an aqueous solution. Abstracts of communications of The International Conference dedicated to the 55th anniversary from the foundation of the Institute of Chemistry of the Academy of Sciences of Moldova. Chisinau, Moldova, May 28-30, 2014, p. 173.

48. Mukerjee, P.; Ostrow, J.D. Effects of added dimethylsulfoxide on $\mathrm{pK} \alpha$ values of uncharged organic acids and $\mathrm{pH}$ values of aqueous buffers. Tetrahedron Letters, 1998, 39, pp. 423-426.

49. Barbosa, J.; Barron, D.; Buti, S.; Marques, I. Assignment of $\mathrm{pH}_{\mathrm{S}}$ values of reference buffer solutions for standardization of potentiometric sensors in THF-water. Polyhedron, 1999, 18, pp. 3361-3367.

50. Friberg, L.; Nordberg, G.F.; Vouk, V.B. Handbook on the toxicology of metals. Vol. II. Elsevier: Amsterdam, 1986, pp. 276-297.

51. Povar, I. Buffer properties of heterogeneous systems containing sparingly soluble acids and metal hydroxides. Russian Journal of Inorganic Chemistry, 1996, 41, pp. 1167-1172.

52. Allison Geoscience Consultants. MINTEQA2/PRODEFA2, A Geochemical Assessment Model for Environmental Systems: User Manual Supplement for Version 4.0. Inc. Flowery Branch: Georgia, 1998.

53. Povar, I.; Spinu, O. Buffer capacity for heterogeneous aqueous systems. Abstracts of the V-th International Conference "Ecological Chemistry". Chisinau, Moldova, March 2-3, 2012, p. 56.

54. Povar, I. Thermodynamics of the Complex Chemical Equilibria in Heterogeneous Systems "Solid Phase Multicomponent Aqueous Solution". D.Sc. Thesis, Kishinev, Moldova, 1998 (in Russian and Romanian).

55. Povar I. Relationship between the temperature coefficients of the equilibrium concentration of the components and the buffer properties of a system. Russian Journal of Inorganic Chemistry, 1995, 40, pp. 668- 671.

56. Janjic̈, T.J.; Milosavljevic, E.B. Two-phase buffer systems in which acid dimerization occurs in the organic phase. Analityca and Chimica Acta, 1980, 120, pp. 101-109.

57. Povar, I.; Spinu, O. Acid-Base Buffer Properties of Heterogeneous Multicomponent Extraction Systems. Solvent Extraction and Ion Exchange, 2015, 33(2), pp. 196-209.

58. Kalembkiewicz, J.; Szlachta, J. Studies on the Physical Chemistry of (2,4-Dichlorophenoxy) acetic Acid in Twophase Systems Organic Solvent-Water. Journal of Solution Chemistry, 2007, 36, pp. 211-220. 